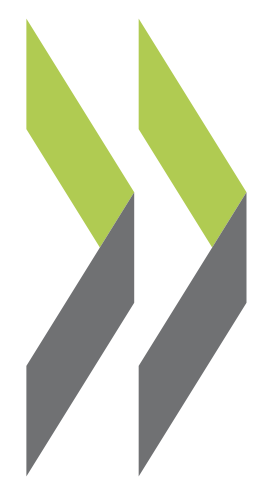

OECD Working Papers on International Investment 2013/01

China Investment Policy: An

Update

\title{
Ken Davies
}

https://dx.doi.org/10.1787/5k469/1hmvbt-en 


\section{OECD WORKING PAPERS ON INTERNATIONAL INVESTMENT}

The international investment working paper series - including policies and trends and the broader implications of multinational enterprise - is designed to make available to a wide readership selected studies by the OECD Investment Committee, OECD Investment Division staff, or by outside consultants working on OECD Investment Committee projects.

The papers are generally available only in their original language English or French with a summary in the other if available.

This work is published on the responsibility of the Secretary-General of the OECD. The opinions expressed and arguments employed herein do not necessarily reflect the official views of the Organisation or of the governments of its member countries.

This document and any map included herein are without prejudice to the status of or sovereignty over any territory, to the delimitation of international frontiers and boundaries and to the name of any territory, city or area.

Comment on the series is welcome, and should be sent to either investment@oecd.org or the Investment Division, OECD, 2, rue André Pascal, 75775 PARIS CEDEX 16, France.

\section{OECD WORKING PAPERS ON INTERNATIONAL INVESTMENT}

are published on:

www.oecd.org/daf/inv/investment-policy/working-papers.htm

(C) OECD 2013

Applications for permission to reproduce or translate all or part of this material should be made to:

OECD Publishing, rights@oecd.org or by fax 33145249930. 


\title{
Abstract \\ CHINA INVESTMENT POLICY: AN UPDATE
}

\author{
By Ken Davies*
}

This working paper examines China's investment policy since the publication of the 2008 OECD Investment Policy Review of China.

China remains the largest recipient of FDI among developing countries and FDI continues to play a disproportionately large role in promoting China's trade, investment and tax revenue generation, albeit not as large as before. A number of structural changes occurred in recent years, including a slight revival of equity joint ventures, faster growth in services-sector FDI than in manufacturing, and a reorientation of FDI from the Eastern Region to the Central and Western Regions. In addition, China has been rapidly becoming an important source of outward foreign direct investment (OFDI), a trend that was reinforced by the global financial and economic crisis.

While foreign investor confidence is maintained by China's economic strength, it is being undermined by rising labour costs and shortages of skilled labour and by greater competition (especially from Chinese companies). In addition, there are fears that an investment protectionist trend may be emerging in China, as evidenced by, for example, perceived discrimination against foreign-owned companies in government procurement.

The Chinese government has taken a number of measures to streamline and decentralise FDI administration and strengthen enforcement. The emphasis has been on aligning inward FDI flows more closely with national priorities, including upgrading industrial sophistication, supporting innovation, setting up outsourcing industries and developing poorer hinterland regions. The most important change is the three-fold raising of the ceiling on provincial examination and approval authority over foreign investment projects in the "permitted catalogue". Merger notification discrimination against foreign investors has been removed and a national security review process for cross-border M\&As has been announced. The Chinese government should continue its efforts to liberalise and increase the transparency and predictability of the framework for both inward and outward FDI.

JEL Classification: F02, F21, F23, F52, F63, G34, L21, L32

Keywords: China; foreign investment; international investment; level playing field; international investment agreements; investment treaties; bilateral investment treaties, state-owned enterprises.

\footnotetext{
* This report was written by Ken Davies (Consultant for the OECD Investment Division). It also benefited from comments by Michael Gestrin and Andrea Goldstein (OECD Investment Division). To contact the author, email: kendavies@yahoo.com.
}

Further information on investment for investment work at the OECD may be found at www.oecd.org/investment 



\section{TABLE OF CONTENTS}

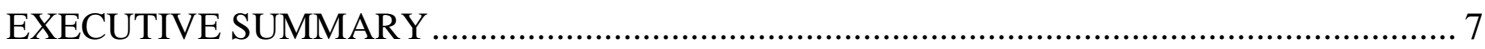

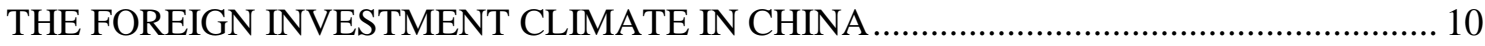

Recent trends in foreign direct investment (FDI) inflows to China.......................................... 10

Developments in government policies towards foreign investment since 2008 ..................... 20

The 2011 Foreign Investment Industrial Guidance Catalogue .............................................. 28

Lessons from recent foreign investor experiences in China ................................................ 29

There has been some progress on IPR protection, but more efforts are needed ....................... 32

The FDI policy framework has improved, but remains restrictive ......................................... 33

RECENT DEVELOPMENTS IN CHINA'S OUTWARD FDI POLICIES …............................. 34

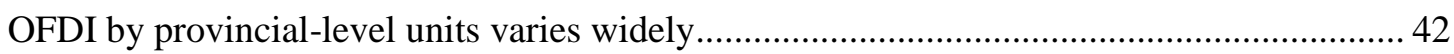

Divergent local policies towards outward FDI are starting to become apparent ..................... 43

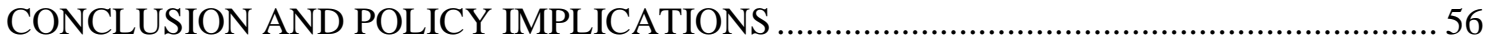

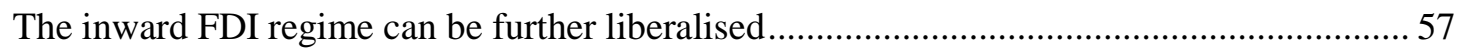

The "go global" policy has been successful .............................................................................. 57

Greater transparency at central level can help maintain rapid OFDI growth .......................... 58

Provinces can benefit from greater policy and data transparency ........................................59

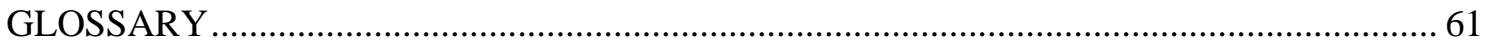

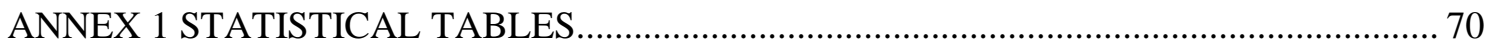





\section{EXECUTIVE SUMMARY}

While China remains the largest recipient of FDI among developing countries. FDI inflows are no longer an increasing contributor to the country's trade surplus, industrial output, fixed investment or tax revenues. This is mainly due to dynamic GDP growth, but also to a more selective - though still open - policy approach. Nevertheless, FDI continues to play a disproportionately large role in promoting China's trade, investment and tax revenue generation, albeit not as large as before.

A number of structural changes occurred in recent years. The first one concerns the form of entry. While wholly-foreign-owned enterprises became the dominant form of inward FDI in China, there has been a slight revival of equity joint ventures. Earlier ownership forms like contractual joint ventures, which were introduced in the early 1980s as an initial entry method for FDI designed to allow foreign participation in the economy while limiting foreign control of enterprises, have meanwhile dwindled to insignificance. The second change concerns the industrial classification. Services-sector FDI is now growing faster than FDI in manufacturing. As China becomes richer and a middle class emerges, foreign investors are attracted to the domestic market. In addition, as wages have begun to rise steadily in the country's export manufacturing centres in the eastern coastal region, other countries have become more competitive than China in labour-intensive industries.

At the same time, wage and other upward cost pressures have started to do what the government's regional policy had previously found difficult: shift economic growth westward from the Eastern Region to the Central and Western Regions. For much of the reform period, GDP growth was fastest in the Eastern Region, driven by the growth of export industries and infrastructure construction. In the 2000s, a policy of investing in hinterland investment construction initially failed to attract investment from outside. More recently, FDI has started to grow more rapidly in the Central and Western Regions. Nevertheless, in the most recent year for which figures have been published, 2010, the Eastern Region continued to absorb the overwhelming majority of foreign investment by number of projects and utilised foreign investment value.

While foreign investor confidence is maintained by China's economic strength, it is being undermined by rising labour costs and shortages of skilled labour and by greater competition (especially from Chinese companies). In addition, there are fears that an investment protectionist trend may be emerging in China, as evidenced by, for example, perceived discrimination against foreignowned companies in government procurement. 
China is not a member of the WTO Government Procurement Agreement (GPA), so it does not have to open its government procurement to companies outside China, though it is currently in the process of submitting a third application to join the GPA. This is fundamentally a trade issue. It becomes, however, an investment issue if the government discriminates in favour of Chinese-owned companies in disregarding or downgrading bids from foreign-invested enterprises based in China and incorporated under Chinese law. Such discrimination has taken place as part of China's "indigenous innovation policy", which until recently giving preference to domestic companies using new technology. This policy has now been dropped. In January 2011, it was announced in a joint US-China statement that "China will not link its innovation policies to the provision of government procurement preferences." It remains to be determined to what extent the policy has now changed sufficiently to provide a level playing field for domestic and foreign-invested enterprises bidding on government contracts.

The Chinese government has taken a number of measures to streamline and decentralise FDI administration and strengthen enforcement since the publication of the 2008 OECD Investment Policy Review of China. The emphasis has been on aligning inward FDI flows more closely with national priorities, including upgrading industrial sophistication, supporting innovation, setting up outsourcing industries and developing poorer hinterland regions. The most important change is the three-fold raising of the ceiling on provincial examination and approval authority over foreign investment projects in the "permitted catalogue". Merger notification discrimination against foreign investors has been removed and a national security review process for cross-border M\&As has been announced.

China has been rapidly becoming an important source of outward foreign direct investment (OFDI) in recent years, a trend that was reinforced by the global financial and economic crisis. The "go global" policy encouraging OFDI by Chinese enterprises has been strengthened and further elaborated since the 2008 Review. As with previous Five Year Plans, it continues to be stressed in the current Five-Year Plan for 2011-2015, both directly and as part of the policy of promoting national champions. The government is gradually lightening the administrative burden on enterprises applying for examination and approval before investing abroad, though the process still involves much red tape, as described in the 2008 Review.

While most outward FDI is still from large state-owned enterprises (SOEs) and other public sector companies, the government is striving to improve conditions for private and small and mediumsized enterprises (SMEs). As outward FDI projects become larger and the external environment more complex, the government is concerned to improve risk forecasting and mitigation. One result of this is that more efforts are being made to encourage responsible business conduct.

Companies owned by local governments (provinces and municipalities) are emerging as important outward investors. While some coastal provinces and major cities became involved in outward investment at an early stage during the economic reform period that began at the end of 1978, other provinces in the interior had no outward investments before the adoption of the "go global"

\footnotetext{
${ }^{1}$ U.S.-China Joint Statement, White House website: http://www.whitehouse.gov.
} 
policy at the turn of the century. As outward FDI accelerated in the second half of the 2000s, the number of outward investment projects has increased markedly, as has average project size.

Sourcing of outward FDI in China remains very unevenly distributed, with coastal cities and provinces responsible for the overwhelming majority of OFDI stock and inland provinces exporting little or no capital. Provincial-level government policies towards outward FDI remain far less transparent than corresponding policies towards inward FDI or indeed than the central government's "go global" policy. The limited information available shows that provinces are developing a differentiated strategy based on economic and locational factors. Some common features are starting to emerge in those provinces and major cities that have more, and more developed, outward FDI, including a preference for coordinated outward investment by firms, for example by joint outward investment promotion and by clustering in special economic zones established in host countries.

The Chinese government should continue its efforts to liberalise and increase the transparency and predictability of the framework for both inward and outward FDI.

Greater transparency at central government level would help allay host country suspicions regarding the intentions of China's outward-investing enterprises and hence sustain the success of the "go global" policy. A first step in this direction would be to collect and publicise more and better OFDI data on the Ministry of Commerce (MOFCOM) investment website.

A rich fund of OFDI experience is being accumulated by the provinces. A comparative analysis of the strengths and weaknesses of these policies could be an important boost to policy development. Provinces themselves can also benefit from greater transparency concerning OFDI statistics and policies, in particular their encouragement to outward-investing enterprises to comply with international norms of responsible business conduct. 


\section{THE FOREIGN INVESTMENT CLIMATE IN CHINA}

\section{Recent trends in foreign direct investment (FDI) inflows to China \\ China's FDI inflows held up well during the global crisis and have recovered strongly}

China has made impressive progress in developing a regulatory framework to attract and promote investment over the past three decades, though challenges remain. ${ }^{2}$ Policies to encourage foreign direct investment (FDI) have been highly successful.

Despite increasing competition from other investment destinations in recent years, China continues to be cited as a favourite destination for foreign direct investment in surveys of investor sentiment. ${ }^{3}$

This sentiment is supported by the statistics: by 2010, China had accumulated FDI stock of USD 579 billion, well ahead of other large developing and transition economies, and from 2000 to 2010 China each year received larger FDI inflows than any other developing or transition economy. ${ }^{4}$

During the recent global economic crisis, the fall in FDI to China was small compared to the global FDI contraction, ${ }^{5}$ indicating - as in the 1997-1998 Asian economic crisis, when FDI flows to China also held up well while collapsing elsewhere in the region - that China is seen as a riskavoidance haven. In 2010, FDI inflows to China recovered strongly, by $17.4 \%$ year-on-year to reach a record high of USD 105.7 billion. ${ }^{6}$ In 2011, realized FDI rose $11.3 \%$ to USD 117.7 billion before decreasing by $3.7 \%$ to USD 113.3 in $2012 .^{7}$

${ }^{2}$ OECD (2003), OECD (2006) and OECD (2008).

${ }^{3}$ For example, China has been in $1^{\text {st }}$ position from 2002 to 2012 in the A.T. Kearney FDI Confidence Index, A.T. Kearney (2010).

${ }^{4}$ Davies (2012).

${ }^{5}$ FDI to China rose by $11.8 \%$ to USD 92.4 billion in 2008, then fell by only $2.6 \%$, from USD 92.4 billion to USD 90 billion in 2009 (see Annex Table 1). By contrast, global FDI flows contracted by $11.5 \%$ in 2008 and 32\% in 2009 (UNCTAD FDI data, at http://unctadstat.unctad.org). In 2010, China's FDI inflows recovered by $17.4 \%$ while global inflows - including, of course, China's - rose by $4.9 \%$ (same source).

${ }^{6}$ See Annex 1 Table 1.

${ }^{7}$ MOFCOM website: $w w w . f d i . g o v . c n$. 
Figure 1 Annual FDI inflows to China, 1982-2012 (USD million)

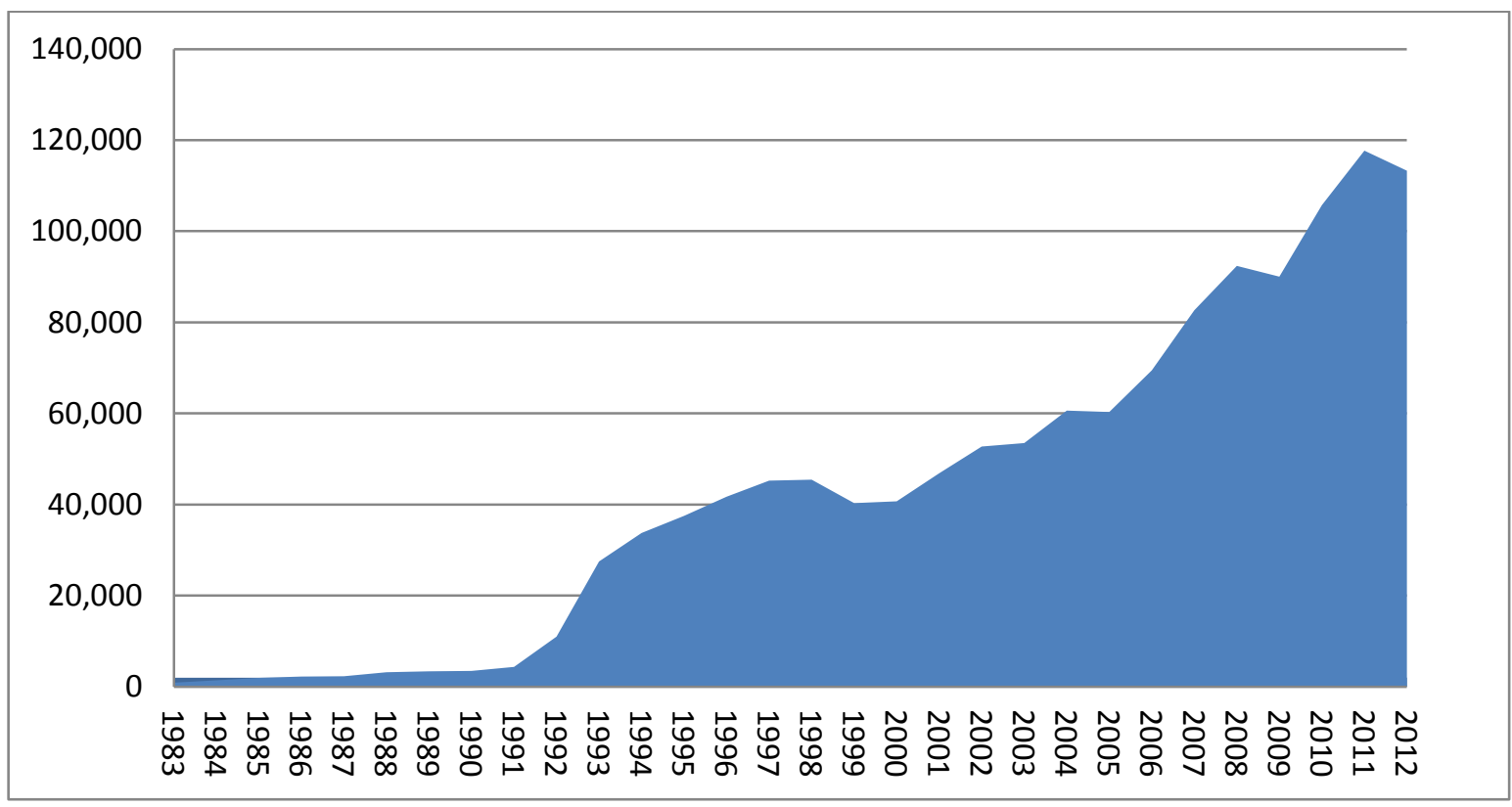

Source: MOFCOM website: www.fdi.gov.cn.

\section{The geographical distribution of China's FDI inflows is not precisely known}

As in previous years, ${ }^{8}$ Asia remains the dominant source of FDI inflows (see Table 1, below), with ten Asian economies providing 66.6\% in 2010, the latest year for which MOFCOM currently provides data on its website. Hong Kong (China) has been the largest single FDI source since the country opened to foreign investment in the late 1970s. While there are some large investors based in Hong Kong (China), there is undoubtedly a high proportion of capital routed through Hong Kong (China) from other parts of the world, as well as continued "round-tripping" of Chinese investment though the motive for this is weaker since tax incentives for foreign investment were withdrawn in 2008 when China adopted a uniform tax system for domestic and foreign enterprises. Indirect routing and round-tripping may also explain the importance of five jurisdictions (Mauritius, Barbados, the Cayman Islands, British Virgin Islands and Samoa) that provided over 14\% of China's FDI inflows in 2010; by contrast, the European Union and North America combined show up then only as supplying $8 \%$.

${ }^{8}$ OECD 2003, OECD 2006 and OECD 2008. 
Table 1. Sources of China's FDI inflows in 2010 (USD million)

\begin{tabular}{|c|c|c|}
\hline Origin & FDI inflow & $\%$ of total \\
\hline 10 Asian economies & $76,462.4$ & 66.6 \\
\hline Hong Kong, SAR & $61,566.8$ & 52.8 \\
\hline Indonesia & 76.8 & 0.1 \\
\hline Japan & $4,083.7$ & 3.6 \\
\hline Macau, SAR & 655.2 & 0.6 \\
\hline Malaysia & 294.3 & 0.3 \\
\hline Philippines & 138.1 & 0.1 \\
\hline Singapore & $5,428.2$ & 4.7 \\
\hline Korea & $2,692.2$ & 2.4 \\
\hline Thailand & 51.3 & 0.0 \\
\hline Chinese Taipei & $2,475.7$ & 2.2 \\
\hline European Union & $5,483.6$ & 4.8 \\
\hline Belgium & 38.4 & 0.0 \\
\hline Denmark & 365.4 & 0.3 \\
\hline United Kingdom & 710.3 & 0.6 \\
\hline Germany & 888.4 & 0.8 \\
\hline France & $1,238.2$ & 1.1 \\
\hline Ireland & 66.4 & 0.1 \\
\hline Italy & 396.1 & 0.4 \\
\hline Luxembourg & 245.5 & 0.2 \\
\hline Netherlands & 914.5 & 0.8 \\
\hline Greece & 4.5 & - \\
\hline Portugal & 10.6 & 0.0 \\
\hline Spain & 254.5 & 0.2 \\
\hline Austria & 125.3 & 0.1 \\
\hline Finland & 64.5 & 0.1 \\
\hline Sweden & 161.1 & 0.1 \\
\hline North America & $3,652.2$ & 3.2 \\
\hline Canada & 634.9 & 0.6 \\
\hline United States & $3,017.3$ & 2.6 \\
\hline Major free ports & $16,004.2$ & 14.0 \\
\hline Mauritius & 928.8 & 0.8 \\
\hline Barbados & 355.8 & 0.3 \\
\hline Cayman Islands & $2,498.8$ & 2.2 \\
\hline British Virgin Islands & $10,447.3$ & 9.1 \\
\hline Western Samoa & $1,773.3$ & 1.6 \\
\hline Total, including others & $114,734.2$ & 100.0 \\
\hline
\end{tabular}

Source: MOFCOM website, www.fdi.gov.cn. 
More is known about the regional destination of IFDI. In recent years wage and other upward cost pressures have shifted economic growth westward from the Eastern Region to the Central and Western Regions. Market forces have made investment in hinterland more convenient, something that a deliberate policy of investing in investment construction had initially failed to achieve. Still, in 2010, the most recent year for which figures have been published, the Eastern Region continued to absorb the overwhelming majority of foreign investment by number of projects and utilised foreign investment value (see Tables $2 \& 3$, below).

Table 2. Cumulative FDI in China's three regions up to end-2010 (USD billion)

\begin{tabular}{|lrrrr|}
\hline & No. of projects & $\%$ & Utilised FDI & $\%$ \\
\hline Eastern Region & 592,274 & 83.3 & 909 & 82.1 \\
Central Region & 75,909 & 10.7 & 85 & 7.7 \\
Western Region & 42,458 & 6.0 & 56 & 5.1 \\
Government & 106 & 0.0 & 57 & 5.1 \\
\hline TOTAL & $\mathbf{7 1 0 , 7 4 7}$ & $\mathbf{1 0 0 . 0}$ & $\mathbf{1 , 1 0 8}$ & $\mathbf{1 0 0 . 0 0}$ \\
\hline
\end{tabular}

Source: MOFCOM website: www.fdi.gov.cn

Table 3. FDI inflow to China's three regions in 2010 (USD billion)

\begin{tabular}{|lrlrr|}
\hline & No. of projects & $\%$ & Utilised FDI & $\%$ \\
\hline Eastern Region & 22,992 & 83.9 & 90 & 78.3 \\
Central Region & 3,056 & 11.1 & 7 & 6.0 \\
Western Region & 1,358 & 5.0 & 9 & 7.9 \\
Government & 14 & 0.1 & 9 & 7.8 \\
\hline TOTAL & $\mathbf{2 7 , 4 2 0}$ & $\mathbf{1 0 0 . 0}$ & $\mathbf{1 1 5}$ & $\mathbf{1 0 0 . 0 0}$ \\
\hline
\end{tabular}

Source: MOFCOM website: www.fdi.gov.cn

\section{Services-sector FDI is growing faster than FDI in manufacturing}

In 2000, the year before China committed to opening services sectors to FDI over a five-year period under the terms of accession to the WTO, tertiary-sector FDI comprised 30.5\% of realised FDI inflow value ${ }^{9}$; by 2008, the share had grown to $52.3 \% .{ }^{10}$ From 2000 to 2010 , in manufacturing the share of actually utilised FDI fell from $63.5 \%$ to $43.2 \%$. ${ }^{11}$ During that time, financial-sector FDI rose from $0.2 \%$ (banking and insurance) ${ }^{12}$ to $8.8 \%$ (finance) ${ }^{13}$, while FDI in real estate increased from

\footnotetext{
${ }^{9}$ OECD (2003).

${ }^{10}$ Davies (2010a).

${ }^{11}$ See Annex 1 Table 3.

${ }^{12}$ OECD (2003).

${ }^{13}$ See Annex 1 Table 3.
} 
$11.4 \%{ }^{14}$ to $20.9 \%{ }^{15}$ This sectoral shift in FDI reflects two factors: the opening up of services sectors to FDI but also the increasing competitiveness of domestic Chinese manufacturing enterprises as a result of SOE and banking reforms.

\section{WFOEs remain dominant, but there has been a slight revival of equity joint ventures}

Wholly-foreign-owned enterprises (WFOEs) became the dominant form of FDI in China in the first decade of this century, rising from $47.3 \%$ of total realized FDI value in $2000^{16}$ to $78.3 \%$ in 2008 before edging below $77 \%$ in 2009 and 2010 before rising slightly to $78.6 \%$ in 2011 and $77.1 \%$ in 2012. ${ }^{17}$ The turn to WFOEs has been largely motivated by a mistrust of Chinese joint-venture partners and facilitated by regulatory liberalisation, which allowed greater scope both for establishing greenfield investments and also for acquiring Chinese enterprises, and greater experience of the Chinese market. ${ }^{18}$ Foreign investors are now also much more familiar with China, its culture and the peculiarities of its business environment than they were when the country was first opened to investment (and to foreigners).

During the recent period, the next largest category, equity joint ventures, fell from $35.2 \%$ of the total in $2000^{19}$ to $18.7 \%$ in 2008 , then rose to $19.2 \%$ in $2009,21.3 \%$ in 2010 , before edging down to 18.6 in 2011 and edging back up to $19.4 \%$ in $2012 .{ }^{20}$ Renewed interest by foreign investors in joining forces with China's domestic enterprises has apparently been provoked by the greater difficulty of acquiring local companies resulting from competition from Chinese firms and the improvement in quality of potential partners. ${ }^{21}$ The continued operation of these factors can be expected to maintain interest in equity joint ventures.

Other modes of FDI entry remain unimportant. Contractual joint ventures, which had accounted for between a quarter and one-third of FDI in the first half of the $1980 \mathrm{~s}^{22}$ fell from $16.2 \%$ in $2000^{23}$ to

\footnotetext{
${ }^{14}$ OECD (2003).

${ }^{15}$ See Annex 1 Table 3.

${ }^{16}$ OECD (2003).

${ }^{17}$ See Annex 1, Table 2.

${ }^{18}$ OECD (2003) and OECD (2006).

${ }^{19}$ OECD (2003).

${ }^{20}$ See Annex 1 Table 2.

${ }^{21}$ Bosshart et al. (2010).

${ }^{22}$ OECD (2003).

${ }^{23}$ OECD (2003).
} 
$2.1 \%$ in $2012 .^{24}$ Joint exploration and compensation trade, which had together initially accounted for half of China's FDI inflows, ${ }^{25}$ have dwindled into insignificance. ${ }^{26}$

\section{FDI has now reached a watershed}

FDI inflows remain strong in absolute terms, but other indicators suggest that the contribution of FDI to China's economy, having climbed rapidly in previous years, started to reach a plateau in the second half of the 2000s. While still important, FDI is no longer an increasing contributor to China's trade surplus, its industrial output, its fixed investment or its tax revenues.

Local authorities have continued to strive to expand the absolute size of FDI inflows into their regions. By contrast, the central government's priority has shifted to improving the quality of FDI rather than just increasing its quantity. FDI plays a crucial role in bringing in new technology to China, where massive domestic spending on science and technology have not yet brought about a matching increase in innovation. A major focus of government policy has been to encourage leading multinationals to shift their R\&D centres to China, while technological innovation has increasingly been stressed in the country's system of catalogues for guiding inward FDI.

The deceleration of FDI inflows has not posed a major problem because it is in major part due to the internal dynamism of China's domestic economy, in particular the development of successful large domestic enterprises whose own contribution to the economy is growing faster than that of foreigninvested enterprises (FIEs). Seen in this light, the end of rapid growth of the FIE share in the Chinese economy is natural, a symptom of the development and maturing of China's economy. Policy-makers may, however, worry that investors - including China's own domestic investors, who now have large sums to invest - are beginning to look further afield for the kind of advantages they previously sought and found in China. This tendency, in part an inevitable result of China's new-found prosperity, may be accentuated by the more selective FDI policy régime that appears to have been developing in China in recent years.

\section{Foreign-invested enterprises' dominance of China's foreign trade is moderating --}

The FIEs' share in China's foreign trade, having risen from nothing at the beginning of the reform period to a peak of $58.5 \%$ in 2005 , moderated subsequently to $53.8 \%$ in $2010,51.1 \%$ in 2011 and $49 \%$ in $2012 .{ }^{27}$

FIEs are an important contributor to the country's massive trade surplus, which has until recently been a major policy goal. From 1986 to 1997 FIE imports exceeded FIE exports; from 1998 onwards,

\footnotetext{
${ }^{24}$ See Annex 1 Table 2.

${ }^{25}$ OECD (2003).

${ }^{26}$ The MOFCOM website shows joint exploration as zero and compensation trade as USD 45 million in 2010: www.fdi.gov.cn.

${ }^{27}$ MOFCOM website: www.fdi.gov.cn.
} 
FIEs have recorded a large surplus of exports over imports (see below for details). ${ }^{28}$ The government can take comfort from the fact that domestic enterprises are now pulling their weight in the export market, but it would presumably not wish to see the trade surplus of foreign-invested enterprises, an important earner of foreign currency, decline too far.

Figure 2. Percentage share of FIE exports and imports in total exports and imports, 1986- 2012

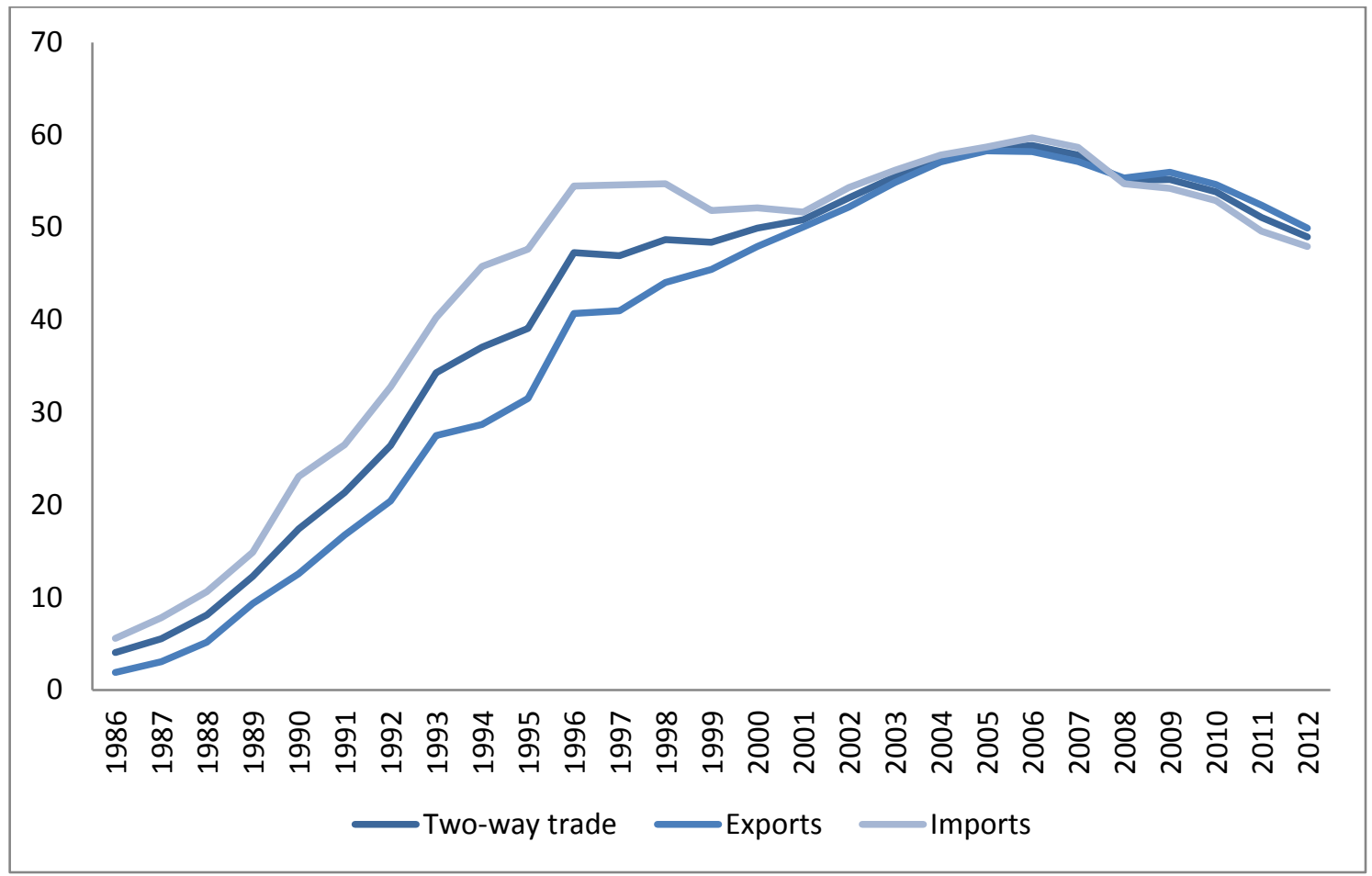

Source: MOFCOM website: www.fdi.gov.cn.

-- and FIEs' trade surplus has risen sharply, though it has fallen since the onset of the global crisis, --

In the early period of FDI attraction up to 1997, FIEs' imports exceeded their exports each year. From 1998 FIEs produced a trade surplus which accelerated rapidly from USD14 billion in 2004 to a peak of USD171 billion in 2008 before falling to USD127 billion in 2009 and USD124 billion in 2010, then recovering modestly to USD 130.5 billion in 2011 and more sharply to USD 151.5 billion in $2012 .^{29}$

The recent falling trend in the FIEs' trade surplus is broadly in line with that of China's overall trade pattern, confirming that FIE net exports are stabilising as a proportion of the national total in the same way as FIEs' two-way trade. It is too early to decide from these statistics whether this is a pause

\footnotetext{
${ }^{28}$ MOFCOM website: $w w w . f d i . g o v . c n$.

${ }^{29}$ MOFCOM web site: $w w w . f d i . g o v . c n$
} 
before a renewed expansion of FIEs' net exports, or an inflection point preceding a downward move as companies increasingly shift their export bases to countries like Vietnam and Indonesia with lower labour costs and improving FDI regulatory frameworks.

Figure 3. FIE trade balance, 1986-2012 (USD billion)

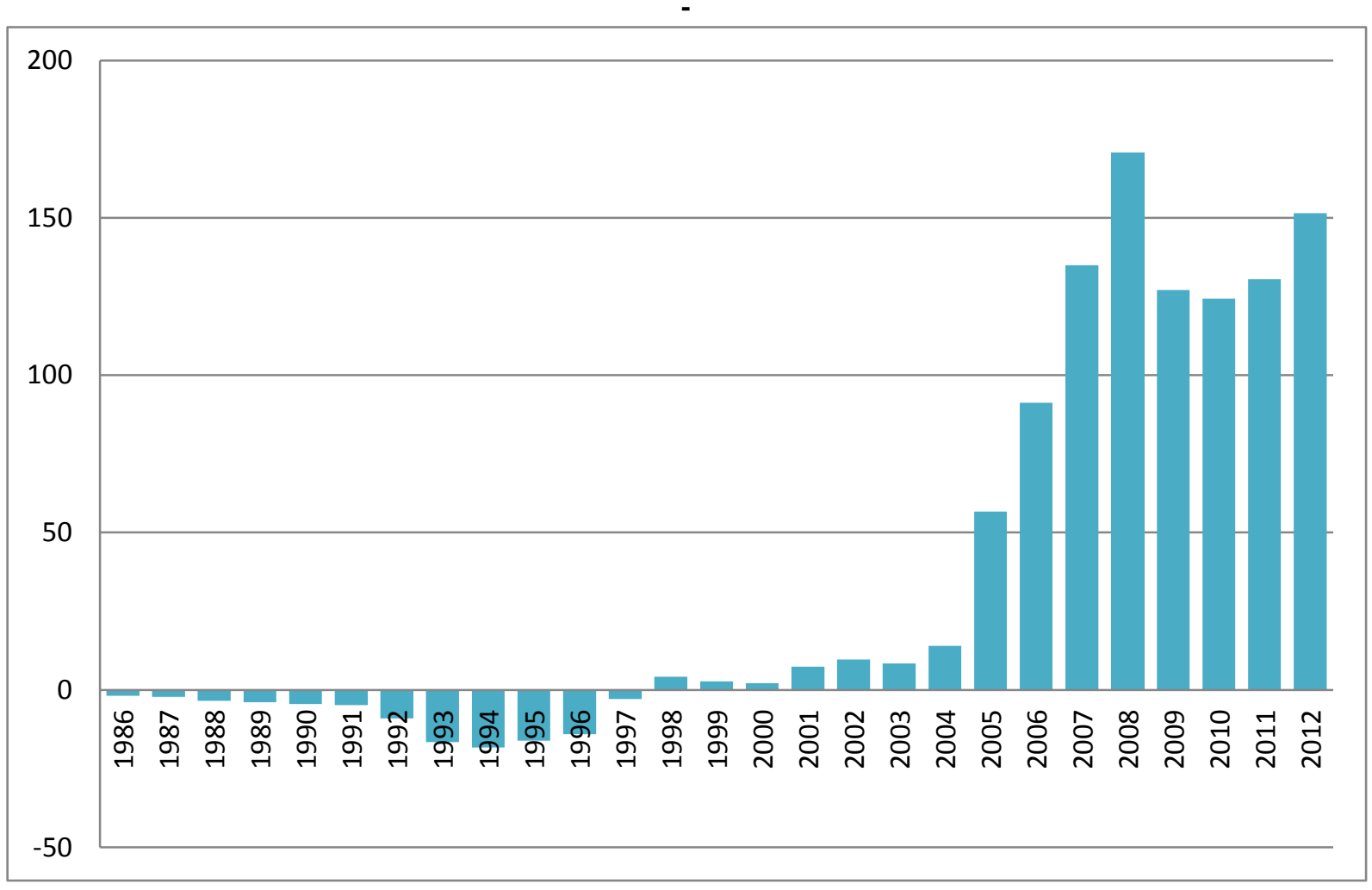

Source: MOFCOM web site: www.fdi.gov.cn.

\section{-- while the share of FIEs in national industrial output is stagnating}

In 1990, over a decade after the initiation of the open-door policy, FIEs accounted for a mere $2.3 \%$ of total national industrial output in value terms. This share then rose steadily to a peak of $35.9 \%$ in 2003 , subsequently declining to around $30 \%$, where it has remained since, edging down to $27.1 \%$ in 2008. This is not because FIEs are producing less - their output rose by an annual average of $23 \%$ between 2003 and 2010 - but because domestic Chinese enterprises have grown faster. 
Figure 4. FIE industrial output as percentage of total, 1990-2010

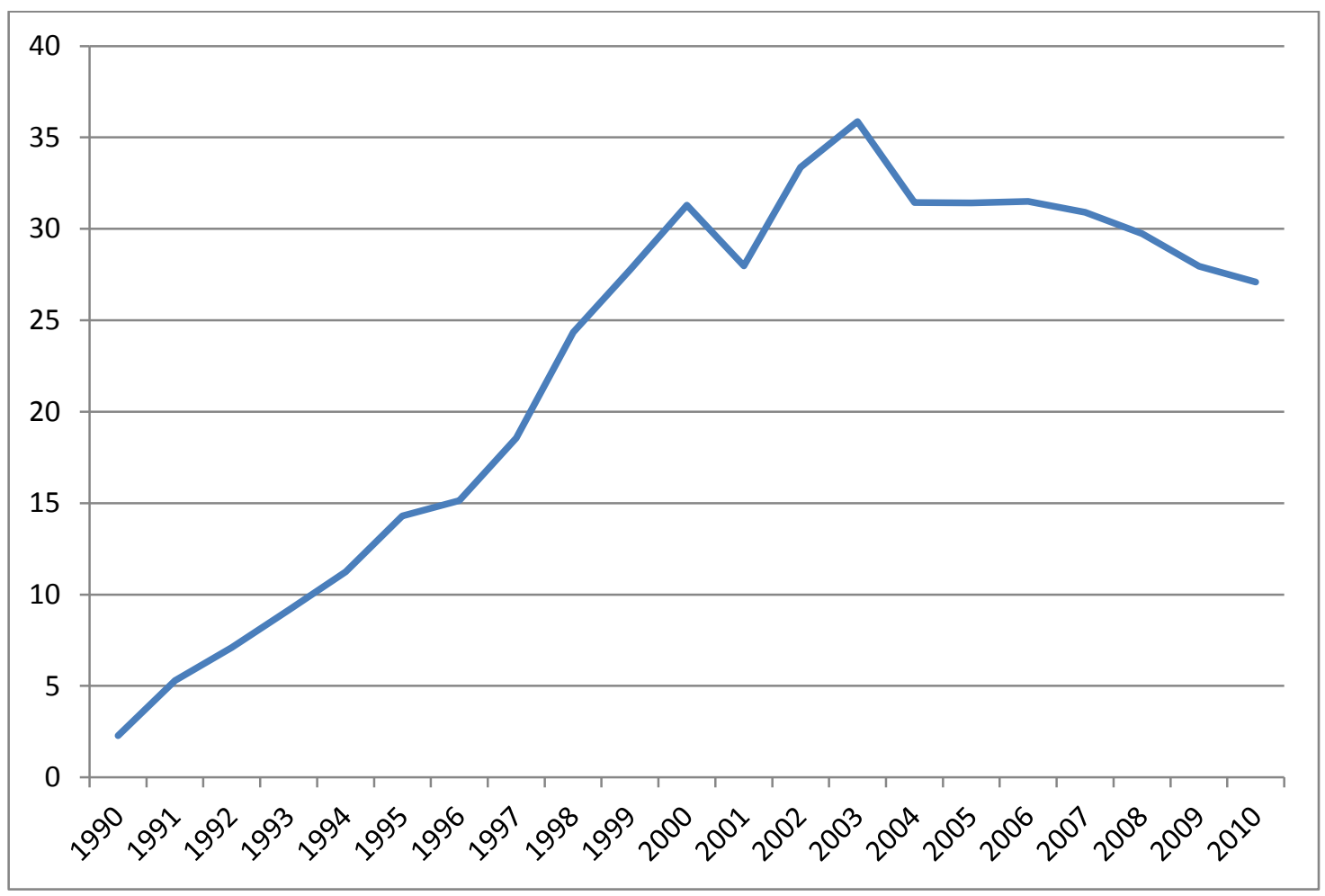

Source: MOFCOM website: www.fdi.gov.cn.

\section{FDI is a declining contributor to capital formation}

Unlike in some small developing countries, FDI has never been a dominant component of capital investment in China. It is difficult to compute the precise contribution of FDI to gross fixed capital formation because total FDI is not coterminous with fixed capital investment. ${ }^{30}$ Total FDI peaked at $17.1 \%$ of fixed capital formation in China in 1993 and has declined since then to $2.8 \%$ in $2010^{31}$, even though it has risen markedly in absolute terms.

${ }^{30}$ FDI reflects the objective of establishing a lasting interest by a resident enterprise in one economy (direct investor) in an enterprise (direct investment enterprise) that is resident in an economy other than that of the direct investor [OECD (2008a), p. 48] while fixed capital investment is defined as the total value of a producer's acquisitions, less disposals, of fixed assets during the accounting period plus certain specified expenditure on services that adds to the value of nonproduced assets [European Commission et al. (2009), p. 198]. While greenfield FDI generally involves the acquisition of such fixed assets, FDI by acquisition does not necessarily do so, as is pointed out by its detractors in developing countries.

${ }^{31}$ MOFCOM website: $w w w . f d i . g o v . c n$. 
Figure 5. Realised FDI as a percentage of gross fixed capital formation in China, 1992-2010

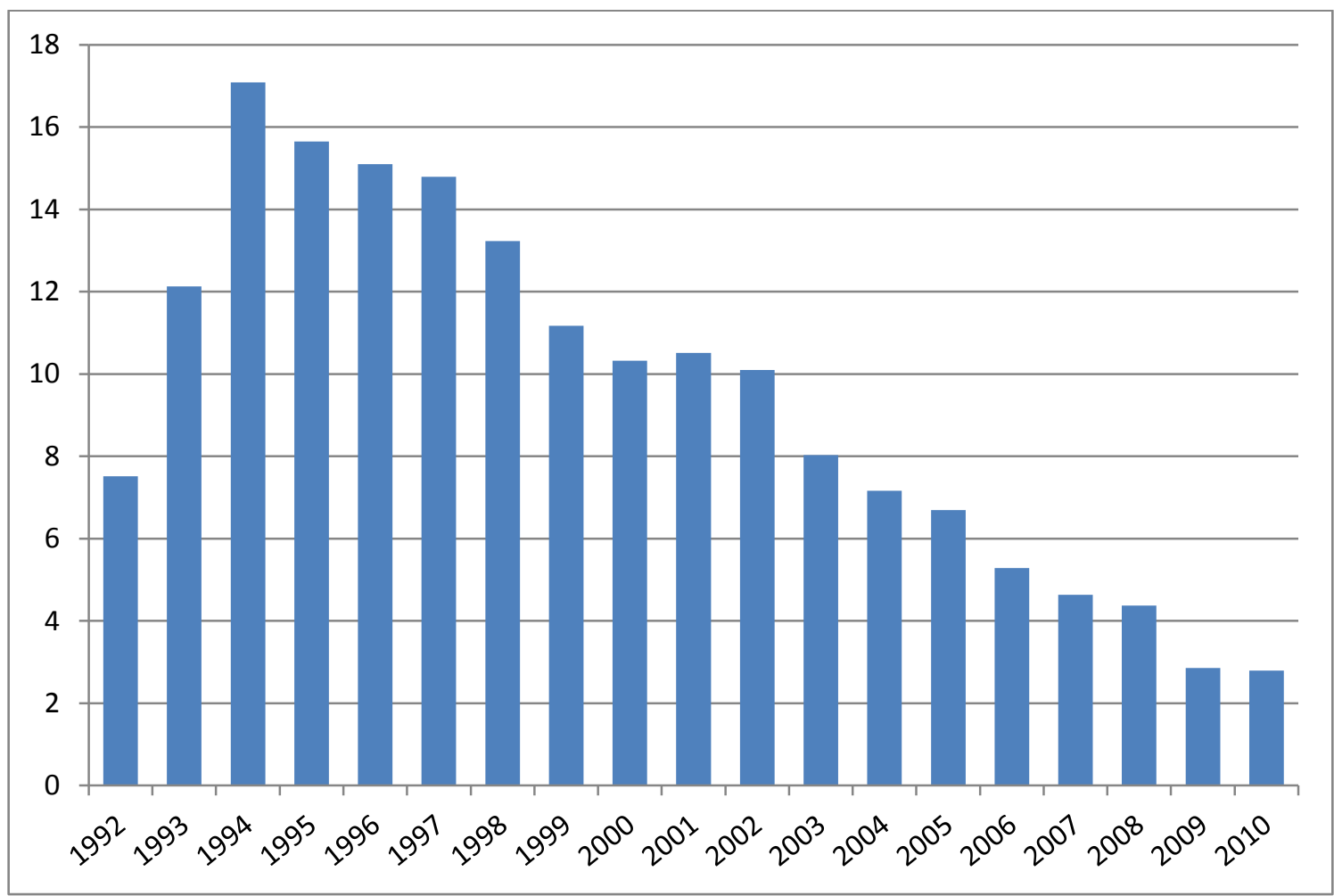

Source: MOFCOM website: www.fdi.gov.cn.

\section{The share of foreign-related tax revenue has stabilised}

In 1992, the year in which FDI began a major acceleration, total foreign-related tax revenue from industry and commerce (excluding customs duties and land fees) amounted to CNY 12.2 billion, just under $4.3 \%$ of national tax revenues from industry and commerce. Tax revenue from foreign-invested enterprises rose far faster than from domestic industry and commerce during the 1990s, so that by 2000 foreign-related tax revenue had reached CNY 221.7 billion, 17.5\% of the total. From 2001 to 2010, the proportion remained remarkably stable at around $20 \%-21 \%^{32}$, despite the marked shift from manufacturing to services FDI during that period (see below).

${ }^{32}$ MOFCOM website: $w w w . f d i . g o v . c n$. 
Figure 6. Foreign-related tax revenue as a percentage of total tax revenue from industry and commerce, 1992-2010

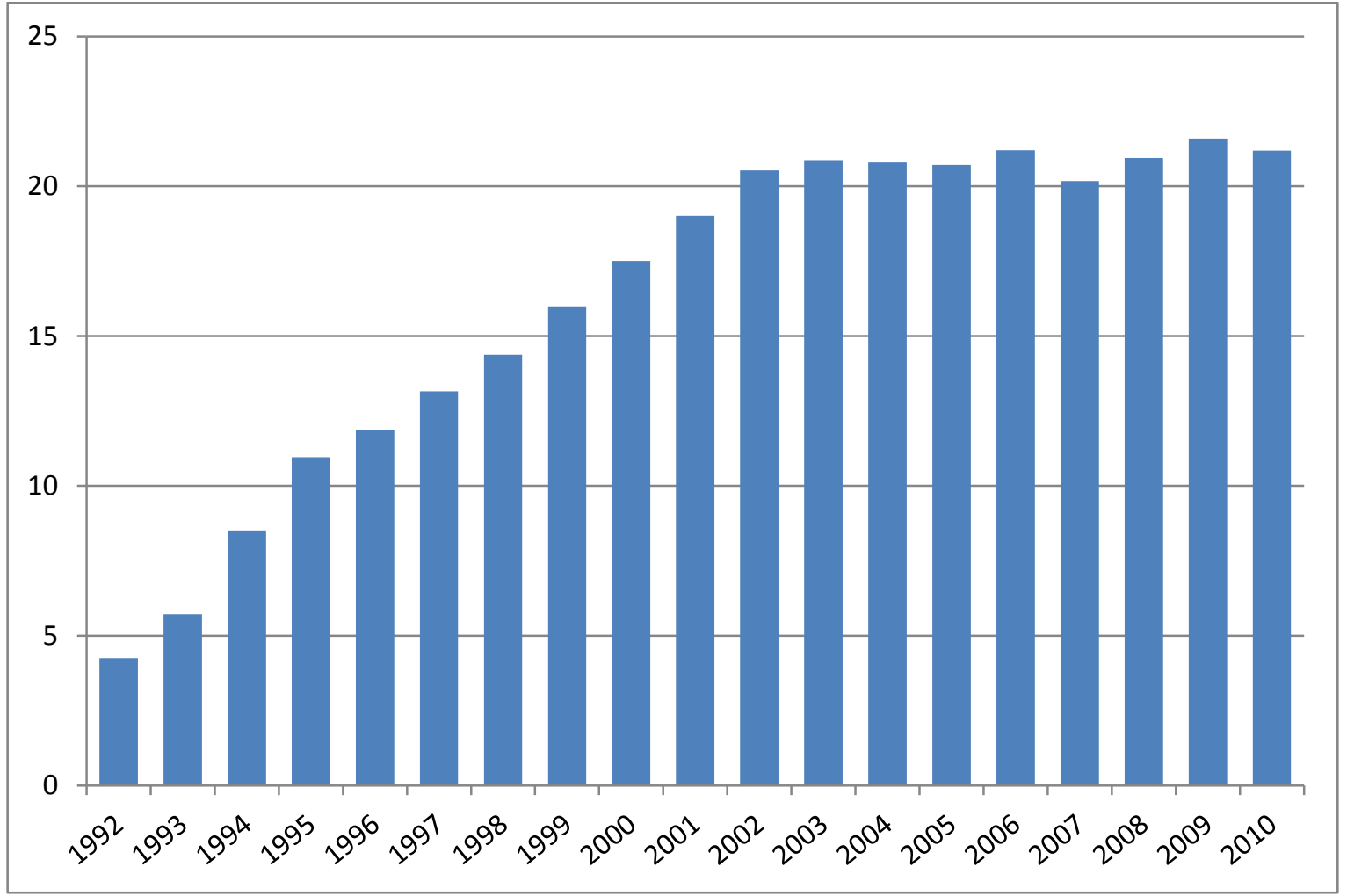

Source: MOFCOM website: www.fdi.gov.cn.

\section{Developments in government policies towards foreign investment since 2008}

\section{Some FDI administrative streamlining has taken place since the 2008 OECD Review}

The Chinese government has taken a number of measures to streamline foreign investment administration since the publication of 2008 OECD Investment Policy Review of China. A number of changes in the foreign investment administration regime were announced in a circular of the State Council, China's cabinet, on 6 April 2010. ${ }^{33}$

The most important change is the raising of the ceiling on provincial examination and approval authority over foreign investment projects in the "permitted catalogue",34 from a total investment of USD100 million to USD300 million. The State Council circular specifies that this delegation of approval applies not only to manufacturing but also to service industries, except for the financial and

\footnotetext{
${ }^{33}$ Several opinions of the State Council on further utilizing foreign capital, Guo Fa (2010) No. 9, 6 April 2010, retrieved from MOFCOM web site www.fdi.gov.cn.

${ }^{34}$ MOFCOM uses four catalogues: permitted, encouraged, restricted and prohibited investment projects. The permitted catalogue is not published. See: OECD (2008), pp. 32-40.
} 
telecommunications sectors. ${ }^{35}$ Projects in the "restricted catalogue" remain unchanged, with provincial-level approval up to USD50 million. This applies both to central and local organs of the Ministry of Commerce (MOFCOM) ${ }^{36}$ and of the National Development and Reform Commission (NDRC) ${ }^{37}$ This delegation of FIE approval power to the provinces continues the trend started in 2004, when the USD100 million limit for provincial approval of projects in the "permitted" and "encouraged" catalogues was put in place. In 2009, MOFCOM delegated approval authority for "encouraged" investment projects to its provincial offices, except in cases involving the national interest and also the authority to approve changes in FIEs already established with central MOFCOM approval. ${ }^{38}$ At the same time, MOFCOM allowed provinces for the first time to examine and approve the establishment of investment (holding) companies up to the then general limit of USD100 million. ${ }^{39}$ In this and subsequent devolvements, MOFCOM devolved not just to provinces (including autonomous regions like Guangxi and the four cities under direct central government control, namely Beijing, Shanghai, Tianjin, and Chongqing) but also to second-tier cities (Harbin, Changchun, Shenyang, Jinan, Nanjing, Hangzhou, Guangzhou, Wuhan, Chengdu, and Xi'an) and Economic and Technological Development Zones.

The State Council circular also stipulates that approval contents shall be "adjusted" (according to criteria that are to be determined) and approval procedures simplified to the maximum and strengthens the transparency of approval. ${ }^{40}$ The circular also strongly promotes online administrative licensing of FIEs. ${ }^{41}$ FIEs that are operating lawfully but temporarily failing to make a payment on time because of lack of capital shall be allowed to extend their contribution deadline. ${ }^{42}$

\footnotetext{
${ }^{35}$ Guo Fa (2010) No. 9, IV (16).

${ }^{36}$ Circular of the Ministry of Commerce on delegating approval authority over foreign investment to local counterparts, Shang Zi Fa (2010) No. 209, 10 June 2010, retrieved from MOFCOM web site www.fdi.gov.cn.

${ }^{37}$ Circular of the National Development and Reform Commission on doing a good job in delegating the power to approve foreign-invested projects, Fa Gai Wai Zi (2010) No. 914, 4 May 2010, retrieved from MOFCOM web site www.fdi.gov.cn.

${ }^{38}$ Notice of MOFCOM on further enhancement of approval procedures for foreign investment, Shang Zi Han (2009) No.7, 5 March 2009, retrieved from MOFCOM web site, www.fdi.gov.cn.

${ }^{39}$ Circular of MOFCOM on delegation of the authority to examine and approve the establishment of investment companies by foreign investors, Shang Zi Han (2009) No.8, 6 March 2009, retrieved from MOFCOM web site www.fdi.gov.cn.

${ }^{40}$ In July 2010 the State Council announced the cancellation of 113 foreign investment examination and approval items and the delegation of a further 71 to lower level administrations as part of the deepening reform of the system. Decision of the State Council on the fifth batch of items subject to administrative examination and approval at the management level to be cancelled or delegated to lower levels, Guo Fa (2010) No. 21, 4 July 2010, retrieved from MOFCOM web site www.fdi.gov.cn.

${ }^{41}$ Guo Fa (2010) No. 9, IV 17.

${ }^{42}$ Guo Fa (2010),No.9, IV 19.
} 
FDI procedures were further simplified in February 2011 by a MOFCOM circular which eliminates the need for examination and approval of the establishment of a branch which is not subject to any special requirement. ${ }^{43}$

The 2010 State Council circular is part of a continuing decentralisation of foreign investment administration. From 26 August 2008, notification of non-material changes (such as change of enterprise name, names of investors, business address, number of directors and statutory business period) has been devolved to commercial departments at the provincial level. ${ }^{44}$ In March 2009 the Ministry of Commerce issued a circular eliminating the examination and approval procedure for importing equipment by FIEs and introducing direct filing for the establishment of a domestic branch by an existing FIE. ${ }^{45}$

At the same time as attempting to streamline foreign investment administration, the government is trying to ensure that procedures are actually followed. Most of the above-mentioned circulars and decrees include strictures to apply policies and laws more effectively. An NDRC circular issued in 2008 states the problem with unusual frankness:

“...issues such as relaxed enforcement of relevant state provisions and improper administration of foreign investment projects still exist in some areas. Some foreign investment projects are under construction without approval; some constructions do not strictly follow the approved contents; and some investors take advantage of the fluctuations of the international capital market and the regulations of Chinese exchange rate policies to introduce funds in the name of FDI by way of false joint ventures, false reports of total investment and the establishment of shell companies, and make exchange settlements...to pursue illegal interests, bringing potential risks for the sound development of the Chinese economy and international payments equilibrium."

The remedy proposed in the Circular is mainly exhortation strictly to enforce foreign investment project approval procedures, improve inspection of the truth of foreign investment projects, administer foreign investment projects by type and scale, regulate the administration of new projects and strictly control approval conditions for all projects, and improve the supervision and inspection of approved projects. ${ }^{46}$

${ }^{43}$ Circular of the Ministry of Commerce on issues concerning foreign investment administration, Shang Zi Han (2011) No. 72 .

${ }^{44}$ Circular of the Ministry of Commerce on further simplifying and regulating the administrative licensing of foreign investment, Shang Zi Han (2008) No.21, 26 August 2008, effective from date of promulgation, retrieved from MOFCOM web site www.fdi.gov.cn.

${ }^{45}$ Circular of the Ministry of Commerce on further improving examination and approval of foreign investment, Shang $\mathrm{Zi} \mathrm{Han}$ (2009) No.7, 5 March 2009, retrieved from MOFCOM web site www.fdi.gov.cn.

${ }^{46}$ Circular of the National Development and Reform Commission on the further enhancement and regulation of the administration of foreign investment projects, Fa Gai Wai Zi (2008), No.1773, 8 July 2008, retrieved from MOFCOM web site www.fdi.gov.cn. 


\section{The aim is to align FDI more closely with national development priorities, --}

The 2010 State Council circular reiterates the government's aim of utilising foreign capital to boost scientific innovation, industrial upgrading and regionally coordinated and balanced development. ${ }^{47}$ Foreign investment is to be encouraged into: high-end manufacturing; high and new technology industry; modern services industries; new energy, energy-saving and environmental protection industries. Foreign investment in high-polluting, high-energy-consuming, resourcedependent, low-level and overcapacity expansion projects are to be restricted. ${ }^{48}$ Domestic and foreign enterprises are to be encouraged to strengthen R\&D co-operation and qualified FIEs encouraged cooperating with domestic enterprises to apply for national scientific development projects and innovation capacity construction projects. ${ }^{49}$ Multinational enterprises shall be encouraged to set up regional headquarters and $R \& D$ centres in China. No tariffs or taxes shall be levied on equipment needed by qualified foreign-funded $R \& D$ centres before $2010 .{ }^{50}$ A number of measures have been taken to improve administration of foreign investment in sectors deemed important by the government, including minerals exploration ${ }^{51}$, advertising ${ }^{52}$, telecommunications ${ }^{53}$, commercial enterprises ${ }^{54}$, printing ${ }^{55}$ and insurance. ${ }^{56}$ The State Council circular also announced that policies shall be implemented and perfected to encourage foreign investment, bring in advanced technologies and management experience and raise the competitiveness of China's services outsourcing industry. ${ }^{57}$ This is part of a national policy that has been developed since the mid-2000s to emulate the development of

${ }^{47}$ Guo Fa (2010) No.9, preamble.

${ }^{48}$ Guo Fa (2010) No.9, I 1, 4.

${ }^{49}$ Guo Fa (2010) No.9, I 5.

${ }^{50}$ Guo Fa (2010), No.9, I 6. This means they are not liable for back tax.

${ }^{51}$ Measures for the administration of foreign-invested mineral exploration enterprises, Decree of MOFCOM and the Ministry of Land and Resources, (2008) No.4, 18 July 2008, retrieved from MOFCOM web site www.fdi.gov.cn.

${ }^{52}$ Provisions for the administration of foreign-invested advertising enterprises, Decree of the State Administration for Industry and Commerce and MOFCOM No. 35, 22 August 2008, retrieved from MOFCOM website www.fdi.gov.cn.

${ }^{53}$ Decision of the State Council on amending provisions on the administration of foreign-invested telecommunications enterprises, Decree of the State Council No.534, 10 September 2008, retrieved from MOFCOM website www.fdi.gov.cn.

${ }^{54}$ Circular of MOFCOM on delegating matters concerning the examination and approval of foreign-invested commercial enterprises, Shang Zi Han (2008) No.51, 12 September 2008. It is not completely clear what is, in this context, the meaning of the Chinese term "shangye" (which normally translates perfectly into "commercial").

${ }^{55}$ Supplementary provisions on the establishment of foreign-invested printing enterprises, Decree No.39 of the General Administration of Press and Publication and MOFCOM, 12 November 2008, retrieved from MOFCOM web site www.fdi.gov.cn.

${ }^{56}$ Interpretation of the China Insurance Regulatory Commission (CIRC) on several issues concerning the application of the Measures for Administration of Representative Offices of Foreign Insurance Institutions in China, Bao Jian Fa (2008) No.101, 14 November 2008, retrieved from MOFCOM web site www.fdi.gov.cn.

${ }^{57}$ Guo Fa (2010) No.9, I 7. 
offshore outsourcing in India. At the beginning of 2009, 20 cities $^{58}$ were identified as demonstration cities for services outsourcing, supported by preferential policies including reduced enterprise income tax and subsidies for graduate employment. As there is no mention in the document announcing this policy of any ownership restriction, these incentives are presumably available to FIEs and domestic enterprises alike. $^{59}$

\section{-- and development of China's poorer hinterland regions}

To support the development of China's Central and Western Regions, which have grown less rapidly than the Eastern Region, the government has since the late 1990s increasingly implemented policies to encourage both domestic and foreign investment there. Most of the incentives are nondiscriminatory, but some are targeted specifically at foreign investors.

A Catalogue of Advantaged Industries for Foreign Investment in the Central and Western Regions came into effect on 1 January 2009. This Catalogue replaced an earlier catalogue for the Central and Western Regions promulgated in 2004 and a similar catalogue relating to Liaoning province in North-East China promulgated in 2006. The new Catalogue covers the provinces of Shanxi, Inner Mongolia, Liaoning, Jilin, Heilongjiang, Anhui, Jiangxi, Henan, Hubei, Hunan and Guangxi. Tibet and Xinjiang, in the Western Region, are not included in the list. For each province, approximately 20 project areas are proposed, ranging from resource exploitation to conservation to manufacturing. ${ }^{60}$ A customs decree in early 2009 extends tariff exemptions on equipment imports for certain foreign investment projects in the Central and Western Regions. ${ }^{61}$

\section{Merger notification discrimination against foreign investors has been removed}

In the 2008 OECD Investment Policy Review of China, it was noted that the discriminatory merger notification procedures in the 2003 Interim Provisions on the Acquisition of Domestic Enterprises by Foreign Investors had been retained in the 2006 Regulations on the Acquisition of Domestic Enterprises by Foreign Investors. The OECD suggested that these procedures be reconsidered and perhaps rescinded to ensure consistency with the Anti-Monopoly Law. The Ministry of Commerce has since replaced the original Chapter 5 on anti-monopoly review in the 2006 Regulations with a new article (Article 51 in the Supplementary Provisions) which states that "According to the provisions of the Anti-Monopoly Law, where M\&A of a domestic enterprise by a foreign investor meets the thresholds for declaration of the Provisions of the State Council on

\footnotetext{
${ }^{58}$ Beijing, Tianjin, Shanghai, Chongqing, Dalian, Shenzhen, Guangzhou, Wuhan, Harbin, Chengdu, Nanjing, XI'an, Jinan, Hangzhou, Hefai, Nanchang, Changsha, Daqing, Suzhou and Wuxi.

${ }^{59}$ Reply of the General Office of the State Council to issues concerning the facilitation of services outsourcing industry, Guo Ban Han (2009) No.9.

${ }^{60}$ Decree of the National Development and Reform Commission and the Ministry of Commerce No.4, 23 December 2008, retrieved from MOFCOM web site www.mofcom.gov.cn.

${ }^{61}$ Public Notice No. 4 (2009) of the General Administration of Customs in implementing the catalogues of foreign-invested industries in Central and Western Regions (Revision of 2008), 19 January 2009, retrieved from MOFCOM web site www.mofcom.gov.cn.
} 
Thresholds for Declaration of Concentrations of Undertakings, the foreign investor shall make a declaration with MOFCOM and shall not carry out the transaction without a declaration." ${ }^{\prime 2}$

So far, although there are far more domestic than cross-border M\&As, decisions to block or add remedial conditions to M\&A deals have been taken only where the acquirer is a foreign-owned enterprise.

Cross-border M\&A deals, both inward and outward, are generally much fewer in number and rather smaller in total value than the domestic M\&A market. For example, in a recent period, 11 November 2011 to 12 January 2012, there were 51 inward M\&A transactions with a total deal value of USD 9,537 million and 37 outward M\&A transactions with a total deal value of USD 9,334 billion; at the same time there were 616 domestic M\&A transactions totaling USD 19,990 million. ${ }^{63}$

By end-November 2011, only ten decisions under the Anti-Monopoly Law had been published by MOFCOM out of well over 300 merger control reviews (since only decisions that prohibit transactions or subject them to conditions are made public), including nine conditional approvals and one notice prohibiting Coca-Cola's acquisition of Huiyuan Juice Group in March 2009. All ten decisions related to M\&A deals by foreign companies, including acquisitions of Chinese domestic companies and mergers between foreign companies outside China where the resulting company would be a major player in the China market, such as the acquisition by Japan's Mitsubishi Rayon Co. of the United Kingdom plastics manufacturer Lucite International Group. The review process is lengthy, because although MOFCOM respects the 30-day decision window in the Anti-Monopoly Law, the start of the review process may be delayed if extra paperwork is required, and the review process can be extended if MOFCOM decides to undertake a second, Phase II, review. While $60 \%$ of cases are reportedly cleared in Phase I, that leaves a substantial number that take an extra 30 days.

Table 4. Merger control cases, 2008-2010

\begin{tabular}{|rrrr|}
\hline & Cleared without conditions & Cleared with conditions & Rejected \\
\hline 2008 & 16 & 1 & 0 \\
2009 & 75 & 4 & 1 \\
2010 & 116 & 1 & 0 \\
\hline
\end{tabular}

Source: Figures provided by Mr. Shang Ming, Director General of MOFCOM's Anti-Monopoly Bureau at the BRICS International Competition Conference 2011, Beijing, 21 September 2011.

${ }^{62}$ No.6 decree of the Ministry of Commerce on the promulgation of the Regulations on the Merger and Acquisition of a Domestic Enterprise by a Foreign Investor, No. 6 Decree of MOFCOM, 2009, 22 June 2009, retrieved from MOFCOM web site www.mofcom.gov.cn.

${ }^{63}$ Figures are from China M\&A Roundup issued on 17 January 2012 by Deloitte China Services Group, based on figures from Thomson. They represent deals at all stages of completion, including completed, unconditional, intended, pending and partially completed. 


\section{A national security review process for cross-border M\&As has been announced}

The 2008 Review noted that the new cross-border M\&A regulations introduced in 2006 included, in addition to the merger notification requirement, a provision for a national economic security review which was not clearly defined. ${ }^{64}$ It also pointed to a lack of clarity in the operation of a national security review applying only to foreign investors in the Anti-Monopoly Law that came into force on 1 August $2008 .^{65}$

The level of transparency in this area of Chinese law has been increased by a State Circular issued in February 2011 which set out draft terms of a national security review for acquisitions of Chinese enterprises by foreign investors. ${ }^{66}$ The public was invited to submit comments to MOFCOM on procedural matters during a feedback window from 5 March 2011 to 10 April $2011 .^{67}$ Based on this feedback, MOFCOM issued a detailed set of national security review procedures for M\&As of domestic enterprises by foreign investors on 25 August 2011 to take effect from 1 September $2011 .^{68}$

The February 2011 Circular states that a national security review is required when foreign investors are considering acquiring military-related enterprises such as: enterprises in the military industry and supporting firms; enterprises in the vicinity of strategic and sensitive military facilities; other units that are related to national defence and security. The other list of enterprises for which a national security review is required by the Circular appear to fall more within the category of "national economic security" introduced in the 2006 cross-border M\&A regulations: major agricultural products, major energy and resources; infrastructure; transport; key technologies; manufacture of

\footnotetext{
${ }^{64}$ OECD (2008), p.16.

${ }^{65}$ OECD (2008), p.31.

${ }^{66}$ Notice of the General Office of the State Council on initiating a security review system for foreign investors seeking to acquire Chinese enterprises, Guo Ban Fa (2011) No.6, 2011, unofficial translation by Squires, Sanders \& Dempsey retrieved from http://www.ssd.com. Foreign M\&A of domestic enterprises is defined to include: purchase of equity or subscription to capital increase of a domestic non-foreign-invested enterprise by foreign investors, thereby converting the enterprises into an FIE; purchase of Chinese shareholders' equity or subscription to capital increase of a domestic FIE by foreign investors; establishment of an FIE by foreign investors which purchase the assets of a domestic enterprise by contract to operate its assets or purchase the equity in a domestic enterprise through the FIE; direct purchase of assets of a domestic enterprise by foreign investors and establishing an FIE to operate the assets. The acquisition of actual control by foreign investors is defined to include situations in which: the foreign investor and its parent company or subsidiary hold more than $50 \%$ of total post-M\&A equity; equity by more than one foreign investors accounts in total for more than $50 \%$ of post-M\&A equity; although total foreign investor post-M\&A equity is less than 50\%, its voting rights are enough substantially to influence resolutions adopted at the shareholders' meeting or the board of directors; any other circumstance under which actual control of a domestic enterprise's operational decisions, financial, personnel, technology and other matters is transferred to foreign investors.

${ }^{67}$ Shang Zi Han (2011) No.8, 4 March 2011, retrieved from MOFCOM web site www.fdi.gov.cn.

${ }^{68}$ No. 53 Announcement of 2011 of the Ministry of Commerce Concerning the Provisions of the Ministry of Commerce for the Implementation the Security Review System for Merger and Acquisition of Domestic Enterprises by Foreign Investors.
} 
major equipment ${ }^{69}$, though some of these are also considered to be important to national security in other countries (for example, "critical infrastructure").

The national security review examines the impact of the proposed M\&A by foreign investors of a domestic enterprise on: national defence and security (including on the domestic capability to produce products or provide services, and on relevant facilities, needed for national defence); stable running of the national economy; public order; R\&D capacity related to key technologies needed for national security. The provisions in the Circular do not cover cross-border M\&As in the financial sector. ${ }^{70}$

Under the terms of the Circular, the national security review is carried out by an inter-ministerial Joint Committee set up by the NDRC and MOFCOM under the leadership of the State Council and including the departments in charge of the industries and sectors related to the proposed foreign acquisition. ${ }^{71}$ Where a foreign investor intends to merge with or acquire a domestic enterprise, the investor files an application with MOFCOM. If the proposed transaction falls within the scope of a national security review, MOFCOM makes a request within five days ${ }^{72}$. Such a review may also be requested by any relevant department under the State Council, any national industry association, any enterprise in the same industry or any upstream or downstream enterprise making a proposal for review through MOFCOM. The Joint Committee then decides whether or not a review is necessary. ${ }^{73}$

In the first stage of the review process, the Joint Committee solicits written opinions from relevant departments within five working days. Comments must be provided within 20 working days. If all relevant departments decide that the transaction will have no impact on national security, the Joint Committee makes a decision within five working days after receipt of all written comments and provides MOFCOM with a written notice. ${ }^{74}$ Presumably the decision will be to allow the transaction to go ahead, but this is not stated in the Circular. If any relevant department decides that the transaction may have an adverse effect on national security, the Joint Committee must begin a special review, which includes a security evaluation, within five days of receiving the written opinions. If the result of this is basic unanimity, the Joint Council makes a review decision and notify it to MOFCOM; if there is substantial disagreement, the review is then passed up to the State Council to make a final determination. ${ }^{75}$ Finally, MOFCOM sends the resulting decision to the applicant. ${ }^{76}$ If the M\&A transaction has caused or will probably cause any significant impact on national security, the Joint

\footnotetext{
${ }^{69}$ Guo Ban Fa (2011) No.6, 1.1.

${ }^{70}$ Guo Ban Fa (2011) No.6, 5.4.

${ }^{71}$ Guo Ban Fa (2011) No.6, 3.1, 3.2, 3.3.

${ }^{72}$ Guo Ban Fa (2011) No.6, 4.1.

${ }^{73}$ Guo Ban Fa (2011) No.6, 4.2.

${ }^{74}$ Guo Ban Fa (2011) No.6, 4.3.

${ }^{75}$ Guo Ban Fa (2011) No.6, 4.3.

${ }^{76}$ Guo Ban Fa (2011) No.6, 4.5.
} 
Committee will request MOFCOM to work with relevant departments to terminate the transaction or take effective measures such as the transfer of equity or assets to eliminate this impact. ${ }^{77}$

\section{The 2011 Foreign Investment Industrial Guidance Catalogue}

Each of the three Reviews examined the three revisions made in 2002, 2005 and 2007 to the four catalogues that were originally adopted in 1997 to guide foreign investment away from discouraged and into encouraged sectors (OECD 2003, OECD 2006, OECD 2008). While the 2002 revision represented a major liberalisation of the catalogues in line with commitments entered into to secure China's WTO accession in December 2001, the two subsequent revisions were clearly aimed less at further opening up to foreign investment and more towards adjusting the aspirational sectoral mix of inward direct investment.

The latest revision of the catalogues, the 2011 Foreign Investment Industrial Guidance Catalogue, was adopted by the NDRC and MOFCOM on 24 December 2011, to take effect on 30 January 2012. As with all previous catalogues, there are three published catalogues (encouraged, restricted and prohibited), with the unpublished fourth catalogue (permitted) deemed to include all sectors not in the other three. The latest revision, like the previous two revisions, involves minor alterations, mainly in the direction of more environmentally-friendly investments, with a number of sub-sectoral adjustments in line with micro-changes in emphasis in the government's industrial policy.

While the "encouraged" catalogue may be helpful as an indication of sectors which foreign investors may find fruitful, the Catalogue system as a whole remains nevertheless a restriction on inward FDI. The restricted catalogue in particular is an obstacle course impeding foreign investment in areas where it is not particularly welcomed but where it has to be allowed, for example because of China's obligations under WTO accession agreements. This is clear from the moving of service sectors from the prohibited to the restricted catalogue in 2002 after it had been agreed with WTO members that these sectors were to be opened within five years of China's accession in December 2001. As noted in the Reviews, this system is not transparent, as not all current sectoral restrictions are included in the Catalogue. As a general rule, manufacturing, with some notable exceptions, is in the unpublished permitted catalogue. There may be more uncertainties about whether or not a services sector is open to foreign investment if it is not included in the published catalogues.

Such uncertainties, coupled with China's FDI screening procedures, to which has now been added the possibility of a lengthy national security review, add to the lack of transparency in the country's regulatory framework for investment. As stated in OECD Reviews, investors, particularly those seeking to make the large, long-term, capital-intensive investments that the Chinese authorities are striving to attract, prefer to do so in a predictable and transparent environment. The presence of so many multinationals in China attests to the progress made of the past three decades of reform and opening up in creating certainty over the general direction of policy. This was especially true when China was a unique FDI destination. Now, however, other large emerging markets are competing with China for such investments and China is losing its labour cost advantage. Also, as Chinese industry

\footnotetext{
${ }^{77}$ Guo Ban Fa (2011) No.6, 4.6.
} 
moves into areas previously occupied by the developed countries, it will be competing for FDI with OECD Member countries, almost all of are more open to FDI than China. Further improvements in transparency will be necessary if China is to maintain its investment attractiveness.

\section{Lessons from recent foreign investor experiences in China}

\section{Foreign investor confidence is buoyed by China's economic strength -}

Representatives of investors from OECD countries continue to express confidence in the resilience of China's economy despite problems in the external economic environment and in the country's enormous growth potential.

In the 2011 Business Confidence Survey conducted for the European Chamber of Commerce in China, $78 \%$ of respondents reported an increase in revenue over the year before, $71 \%$ showed an increase in net profit, $79 \%$ said they were optimistic about further growth within their sector in China, $65 \%$ were confident that the Twelfth Five Year Plan will have a positive impact on the business environment, and $70 \%$ stated that they benefited from China's economic recovery. The proportion of respondents explicitly stating that they saw China as an increasingly important strategic market for their global business rose to $57 \%$ from $40 \%$ the year before. ${ }^{78}$

In its second White Paper on the Chinese economy and Japanese companies, the Japanese Chamber of Commerce and Industry in China in 2011 reports that China is regarded as the most promising market by Japanese companies despite various concerns about increasing competition and rising costs. ${ }^{79}$

The 2011 AmCham-China Business Climate Survey reports that operating conditions for US companies in China are excellent, reflecting general macroeconomic conditions. $85 \%$ of US companies in China surveyed reported revenue growth in 2010, $78 \%$ reported profitable or very profitable performance, $63 \%$ reported margins improved over the year before and $41 \%$ reported margins better than their global margins; $83 \%$ said that they plan to increase investment in China in $2011^{80}$

\section{-- but appears to be undermined by several factors}

On the other hand, these annual surveys of investors from Europe, Japan and the United States continue to reveal growing concerns over rising labour costs and shortages of skilled labour, greatly increased competition from Chinese companies, and a perceived deterioration in some aspects of the regulatory framework.

\footnotetext{
${ }^{78}$ European Chamber of Commerce in China (2011).

${ }^{79}$ Japanese Chamber of Commerce and Industry in China (2011).

${ }^{80}$ American Chamber of Commerce in China (Amcham-China) (2011).
} 


\section{Foreign investors are concerned about rising labour costs and shortages of skilled labour}

As reported in the 2008 OECD Investment Policy Review of China, a Labour Contract Law passed in 2007 and which came into force on 1 January 2008 provides increased protection for workers by providing greater security of employment. ${ }^{81}$ Local governments in coastal provinces have raised minimum wages to encourage factory workers, most of whom are migrant workers [i.e. workers whose household (户口, hukou) registration is in rural areas, not the cities in which they work], not to return to their villages, as has been occurring in recent years. As a result, foreign investors are increasingly reporting rising labour costs as a key concern in their China operations. Japanese companies put the rise in employee wages at the top of the list of their managerial problems in China, reported by $79.6 \%$ of respondents in the 2011 Japanese Chamber survey. ${ }^{82}$ Foreign firms in China also report difficulties in obtaining sufficient skilled labour for their needs and complain of high labour turnover rates.

The rise in wages reflects China's rapid development and is highly desirable from the viewpoint of raising living standards and reducing the inequalities that have developed concomitantly with economic expansion during the three decades of economic reform in China. Both the central government and local governments can be expected to continue to take action to improve the situation of industrial workers in the face of increased labour activism. According to one estimate, strikes and worker protests reached 30,000 in $2009^{83}$. The stimulus programme adopted in 2009 also accords strongly with the government's aim of increasing the incomes of poorer urban and rural residents to reduce income disparities and increase the propensity to consume. Further pressures on labour costs will emerge as industries move up the value chain (or into the Central and Western regions, which are increasingly also attracting workers back from the coastal industrial zone), coupled with the end of the "unlimited supply of labour" situation.

\section{Foreign investors are challenged by greater competition, especially from Chinese companies}

With the rise of China's "national champions", foreign investors are feeling the wind of competition from domestic firms as well as from other FIEs. European investors report that they are facing greater competition from both international and Chinese competitors in the China market. Chinese companies are catching up with their foreign competitors, improving in areas once perceived as the stronghold of FIEs such as brand recognition, marketing and sales capabilities and product quality. ${ }^{84}$ US companies in China surveyed in 2011 report that competition for their products and services in China had increased substantially in 2010 versus 2009 by $5 \%$ in the case of competition

\footnotetext{
${ }^{81}$ OECD (2008).

82 Japanese Chamber of Commerce and Industry in China (2011).

${ }^{83}$ China Labour Bulletin (2011).

${ }^{84}$ European Chamber of Commerce in China (2011).
} 
from imports, $18 \%$ from foreign firms and $29 \%$ from Chinese firms. ${ }^{85}$ Japanese firms also see China becoming a more competitive market as domestic companies come to the forefront. ${ }^{86}$

One of the reasons for inviting foreign investors to come to China and for China's accession to the WTO was to introduce a fresh breeze of competition to stimulate domestic enterprises to modernise and improve their operation. That FIEs are now themselves facing hotter competition is a healthy phenomenon reflecting the success of this FDI-attraction policy. It is natural for companies, including FIEs, to recognise the challenge that competition poses so that this can stimulate them to improve their products and services. To the extent that increased competition is also the result of the Anti-Monopoly Law passed in $2007^{87}$, it should also be welcomed as a result of the improved regulatory framework. FIEs are, though, justified in complaining if they find that they are put in a disadvantageous position vis-à-vis their competitors, for example through unfair government procurement practices, in particular for environmentally clean technologies. ${ }^{88}$

\section{Concerns by foreign investors over restrictive government policies are increasing}

Foreign investors are expressing increasing concern over perceptions that government policies are discriminating against foreign-invested enterprises. For example, in 2011 the percentage of European investors surveyed who thought policies to be discriminatory in this way over the previous two years increased from $33 \%$ to $43 \%$ since a similar survey was conducted in 2010 , while similar perceptions regarding the outlook for the next two years also increased from $36 \%$ to $46 \%$ at the same time. $^{89}$

The European Chamber of Commerce survey showed that the five most significant regulatory obstacles were, in order of the percentage of respondents: discretionary enforcement of broadly drafted laws and regulations (42\%); lack of co-ordination of different regulators (40\%); lack of harmonization with global standards (39\%); registration procedures for companies or for products (38\%); and local implementation of Chinese standards $(35 \%) .{ }^{90}$

More specific concerns were voiced in the 2010 European Chamber survey that China was not living up to its 2001 WTO accession commitments. Only one-fifth of respondents considered that the Chinese government was implementing changes in the spirit of the WTO agreement. ${ }^{91}$

\footnotetext{
${ }^{85}$ American Chamber of Commerce in China (Amcham-China) (2011).

${ }^{86}$ Japanese Chamber of Commerce and Industry in China (2011).

${ }^{87}$ OECD (2008).

${ }^{88}$ As EC Trade Commissioner Karel De Gucht noted, "we keep hearing complaints from European businesses that the

Chinese procurement market is closed and lacks transparency and regularity. This has also spurred a debate in Europe to strengthen 'reciprocity' in our external economic relations" (2011, p. 3).

${ }^{89}$ European Chamber of Commerce in China (2011).

${ }^{90}$ European Chamber of Commerce in China (2011).

${ }^{91}$ European Chamber of Commerce in China (2010).
} 
Respondents in the 2010 European Chamber survey expressed dissatisfaction with the protection of intellectual property rights (IPR) in China. ${ }^{92}$ The 2011 Japanese White Paper also reiterates demands for stronger IPR enforcement and points out that the risk of "leaking technology and knowhow from a business partner" may inhibit Japanese companies from promoting R\&D activities or transferring technologies of China. ${ }^{93}$

While FDI inflows are continuing to increase, it appears that the above-mentioned perceptions are beginning to have a discouraging effect, initially at the margin but potentially much larger. In the European Chamber survey, $20 \%$ of respondents reported that government policies towards foreigninvested enterprises had already led them to suspend new investments, reduce/slow down existing investment plans or reduce/suspend existing investments in China. It is important to note, though, that $15 \%$ of respondents stated that government policies had led them to accelerate planned investments or plan additional investments there. ${ }^{94}$

\section{There has been some progress on IPR protection, but more efforts are needed}

As reported in the Reviews, the protection of intellectual property rights (IPR) is a major concern for foreign investors and may deter foreign investment, particularly in high-tech sectors where multinationals may feel discouraged from bringing their latest technology to China. Inadequate IPR protection damages China's economy, as it makes it more difficult to effect the transition from lowvalue-added assembly operations to high-value-added manufacturing, and it also strongly discourages domestic innovation at a time when the government is spending record sums trying to encourage it.

In April 2007 the United States filed a case against China at the WTO alleging deficiencies in the legal regime for protecting and enforcing copyrights and trademarks, which meant that it was therefore failing to comply with the WTO Trade-Related Aspects of Intellectual Property Rights (TRIPS) agreement. In January 2009 a WTO panel report upheld the complaint that China had not met its obligation to have laws allowing effective action against and remedies for infringing material and providing the same IPR protection to foreign as to domestic IP holders, but also said that China's system for applying criminal penalties on willful, commercial-scale acts of IP infringement were not violating its TRIPS commitments. ${ }^{95}$ In compliance with a deadline of 20 March 2010 set by the WTO for implementing changes in its laws to remedy the situation, several changes were made to relevant laws and notified to the WTO. For example, the Patent Law was revised and amended Implementing Regulations of the Patent Law came into force on 1 February $2011 .^{96}$ These prescribe stricter conditions on granting patents, an improved examination system for patent design and a compulsory licensing system, a new system for preserving evidence in proceedings, supplementary measures to

\footnotetext{
${ }^{92}$ European Chamber of Commerce in China (2010).

93 Japanese Chamber of Commerce and Industry in China (2011).

${ }^{94}$ European Chamber of Commerce in China (2011).

${ }^{95}$ WTO website: www.wto.org.

${ }^{96}$ State Intellectual Property Office of the People's Republic of China (SIPO) website: www.sipo.gov.cn.
} 
protect public interests and stronger patent protection. Also in 2010, the Chinese authorities issued an IPR Protection Action Plan intended to strengthen enforcement. It remains to be determined to what extent these measures are reducing piracy, counterfeiting and other IPR infringements. ${ }^{97}$

\section{The FDI policy framework has improved, but remains restrictive}

As explained above, a number of improvements have been made to the regulatory framework for foreign investment since the publication of the 2008 Review. Nevertheless, as attested to by consistent complaints from foreign investors themselves as represented by the above-cited representative bodies, this framework remains less than wholly transparent and open.

The 2010 OECD FDI Regulatory Restrictiveness Index score for China shows a marked improvement over that for 1997, declining from just over 0.6 to below 0.5 (a score of 1 is wholly closed, 0 is wholly open). ${ }^{98}$ This is the second best improvement in performance after Korea among the countries examined over the same period. Nevertheless, China's 2010 score is the second highest (after Iceland), so China remains far from an economy fully open to foreign investment. Moreover, the 2010 score is slightly higher than that recorded in 2006, suggesting that the liberalisation process has slowed. This is largely a reflection of continuing restrictions on foreign ownership such as those in the Catalogue for Guiding Investment Industries and industrial policy regulations. Easing these restrictions could produce a lower score in future FDI Restrictiveness Index assessments.

\footnotetext{
${ }^{97}$ People's Daily IP Channel website: ip.people.com.cn.

${ }^{98}$ Thomsen (2011). China has not participated in the elaboration of this index and does not recognise its results.
} 


\section{RECENT DEVELOPMENTS IN CHINA'S OUTWARD FDI POLICIES}

The development of China's policy to encourage outward investment from 1979 to the official announcement of the "go global" strategy in 2000 and the implementation of various measures to support this strategy in the mid-2000s was outlined in the OECD's third Investment Policy Review of China published in $2008^{99}$. Since then the "go global" policy has been strengthened and further elaborated.

OFDI flows have grown steadily since 2002, more than doubling between 2007 and 2008 when Chinese investors found themselves in a privileged financial position and could take advantage of the crisis then hitting their competitors in more developed countries. They reached an all-time high in 2010 , with non-financial OFDI growing by $26 \%$ and contributing to $88 \%$ of total Chinese OFDI. As far as international M\&As are concerned, China (including Hong Kong, China) ranked second as the largest source in 2010 with $10 \%$ of the world total and fourth in 2011 , with $7 \%{ }^{100}$

Figure 7. China OFDI flows 1990-2010 (USD billion)

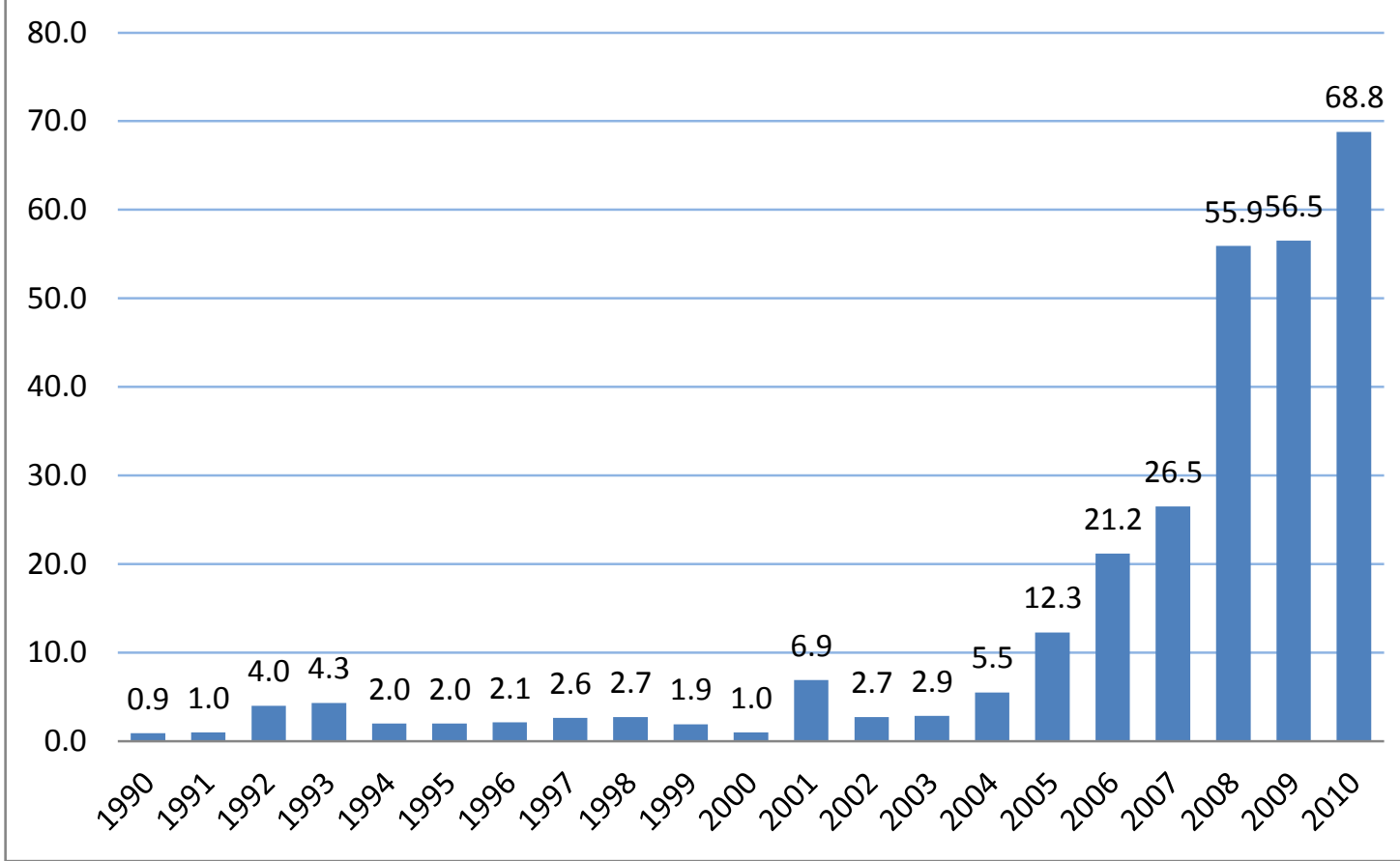

Source: MOFCOM (2011)

${ }^{99}$ OECD (2008), pp.81-93.

${ }^{100}$ Gestrin (2011). 
Table 5. China OFDI in 2010 (USD billion)

\begin{tabular}{|lrrrrr|}
\hline & \multicolumn{3}{c}{ OFDI flow } & \multicolumn{3}{c|}{ OFDI stock } \\
\hline & Amount & \% Change & \% Share & Amount & $\%$ Share \\
Financial & 8.6 & -1.1 & 15.5 & 55.2 & 17.4 \\
Non-financial & 60.2 & 25.9 & 87.5 & 262.0 & 82.6 \\
\hline Total & 68.8 & 1.1 & 100.00 & 317.2 & 100.00 \\
\hline
\end{tabular}

Source: MOFCOM (2011)

\section{The "go global" policy continues to be stressed in the current Five Year Plan}

The "go global" policy was stressed in both the $10^{\text {th }}$ Five Year Plan (2001-2005) and the Eleventh Five Year Plan (2006-2010) ${ }^{101}$. The Twelfth Five Year Plan (2011-2015) maintains it as an objective of China's policy towards international investment. Premier Wen Jiabao, in presenting the outline of the Plan after its approval by the Central Committee of the Communist Party of China in October 2010, said:

"We must accelerate the implementation of the "go global" strategy, in accordance with market orientation and the principle of independent decision-making and guide enterprises with different kinds of ownership to invest overseas and co-operate in an orderly manner."

Premier Wen also urged "protection of China's overseas rights" 102.

In his presentation of this policy in the annual report on the work of the government to the National People's Congress (NPC) on 15 March 2011, Premier Wen reiterated this stance in slightly more specific terms, though again without numerical targets:

"We will accelerate the implementation of the 'go global' strategy, improve relevant support policies, simplify examination and approval procedures, and provide assistance for qualified enterprises and individuals to invest overseas. We will encourage enterprises to operate internationally in an active yet orderly manner. We will strengthen macro guidance over overseas investments, improve the mechanisms for stimulating and protecting them, and guard against investment risks."103

While OFDI (and, for that matter, inward FDI) was absent from the list of key targets announced by the official Chinese media after the Plan was submitted to the NPC in March $2011^{104}$, other policy

\footnotetext{
${ }^{101}$ OECD (2008), p.83.

${ }^{102}$ Central People's Government of the People's Republic of China website, report dated 28 October 2010, retrieved on 19 March 2011.

${ }^{103}$ Wen Jiabao, Report on the Work of the Government, XinhuaNet website, 15 March 2011.

${ }^{104}$ China Daily website, 5 March 2011.
} 
aims that were mentioned on that list may have an impact on policies towards OFDI, in particular the achievement of a "breakthrough in emerging strategic industries"105. These industries include nextgeneration IT, energy conservation, environmental protection, new energy, biotechnology, high-end equipment manufacturing, new materials and new-energy vehicles. ${ }^{106}$ These industries will be the focus of massive Chinese government investment, but it is also likely that domestic enterprises in these sectors will be strongly encouraged to become global, whether by greenfield expansion or by acquisitions of enterprises elsewhere in the world. ${ }^{107}$

\section{China is engaging in an increasingly active investment diplomacy to promote "going global"}

The "go global" policy is likely to be maintained and strengthened by an increasingly active investment diplomacy. ${ }^{108}$ In the period leading up to the formulation of the Twelfth Plan, Chinese enterprises experienced setbacks, including the well-publicised failure of attempted acquisitions in the United States (where CNOOC tried to acquire UNOCAL and Haier and Huawei also failed to clinch important deals) and Australia (box 1). Although the Chinese government - and the official media have repeatedly blamed these failures on "protectionism", there have been some attempts to analyse these episodes so that policies can be framed to avoid similar blocks to large-scale foreign acquisitions by Chinese companies in future.

\footnotetext{
${ }^{105}$ Ibid.

${ }^{106}$ Wen Jiabao, Report on the Work of the Government, XinhuaNet website, 15 March 2011.

${ }^{107}$ On the role of OFDI in the accelerated internationalization of China's emerging global champions, see Bonaglia et al. (2007).

${ }^{108}$ See, for example, Rasiah (2010) and CIGI (2008),
} 


\section{Box 1: Failed Chinese M\&A deals}

CNOOC-UNOCAL: In June 2005, CNOOC made an all-cash USD18.5 billion offer to buy American oil company Unocal, topping an earlier bid by ChevronTexaco. Unocal's extensive oil interests in Central Asia were considered to be an excellent strategic fit for CNOOC. A broad group of Congress representatives organized opposition to the CNOOC bid, arguing that it offer did not represent a free market transaction and had questionable motives that could pose a regional and economic security risk. In July, Unocal announced that it had accepted an increased buyout offer from ChevronTexaco for USD17.1 billion. In August, CNOOC, which was willing to submit to a U.S. security review, announced that it had withdrawn its bid, citing political tension inside the United States.

Haier-Maytag: In June 2005, Haier, the world's largest market share in white goods, and private equity funds Blackstone Group and Bain Capital made a bid to acquire Maytag, the struggling U.S. company, whose iconic brands include Jenn-Air and Hoover. The USD16 per share bid topped a previous offer of USD14 per share made by Ripplewood Holdings. In the end, however, Maytag was bought by Whirlpool Corporation which offered USD21 per share in cash and stock, plus assumed debt.

Huawei-3Com: The Chinese telecom-equipment company tried in 2007 to be the junior partner in a deal led by Bain Capital to take over 3Com in a proposed USD2.2 billion deal. Opposition to the deal built about the security implications of a Chinese company allegedly tied to the People's Liberation Army (a charge that privatelyheld Huawei has consistently denied) gaining access to a second-tier American company. In 2008 the companies withdrew their application to the Committee on Foreign Investment in the United States (CFIUS).

Chinalco-Rio Tinto: In May 2009 Aluminum Corp. of China (Chinalco) announced a USD19.5 billion investment in Rio Tinto. One month later the Rio Tinto board withdrew its support, amid public debate on the growing level of Chinese ownership of Australia's natural resources and shareholder anger over the terms of the deal. In a report, the State Council blamed China's lack of experience, talent and political acuity for the failure. One year later Chinalco and Rio Tinto became joint-venture partners in the Simandou iron ore deposit in Guinea.

Minmetals Resources-Equinox: In April 2011 Minmetals Resources made a USD6.3-billion hostile bid for copper producer Equinox Minerals, but refused to enter a bidding war after Barrick Gold topped the price by USD1-billion.

\section{The government now aims to balance outward and inward FDI}

The overall objective of the Twelfth Five Year Plan is to make China's development better balanced, coordinated and sustainable. ${ }^{109}$ The international component of this policy stance is a move away from dependence on a massive trade surplus and capital inflows, typified by the boasts in earlier years that China had achieved balances on both capital and current accounts.

\footnotetext{
${ }^{109}$ Central planning was officially abolished in 1994 and the former central planning agency has mutated from the State Planning Commission to the present National Development and Reform Commission (NDRC), which retains its rank above that of government ministries and is now responsible for framing indicative, or "guidance", Five Year Plans in lieu of the former mandatory plans. Now that enterprises are no longer all part of government, detailed output targeting is not feasible, even if it were desirable.
} 
In the report presented by the NDRC at the 2011 session of the NPC on economic developments in 2010, there is an evident move towards striving to achieve a balance on both accounts. Trade policy centres on vigorously expanding imports so that both imports and exports can expand at the same rate, while investment policy puts "equal emphasis on [...] attracting foreign capital and making outward investment" ${ }^{\prime 110}$.

A similar objective applies to FDI: Minister of Commerce Chen Deming stated on 7 March 2011 that in 2010 the OFDI:IFDI ratio was 6:10 and that the plan is to steadily reach a balance between OFDI and IFDI (i.e. a 1:1 ratio) within approximately 5-10 years. ${ }^{111}$ The figure he cited for OFDI was non-financial OFDI of USD59 billion, while the IFDI figure of around USD100 billion is for total IFDI, so the government's goal may be even more ambitious, since financial OFDI is not insignificant. $^{112}$

\section{The government is continuing to cut red tape for outward investment project approval}

The government is continuing to reduce the number of stages enterprises have to go through for examination and approval of outward investment projects. While some enterprises have moved enough capital overseas to invest there without this encumbrance, the large corporations, mostly stateowned enterprises, that provide the bulk of China's outward FDI cannot do so and must go through all the official procedures. In promoting the "go global" policy, the government is therefore trying to lighten the administrative burden. The Chinese government points out that its regulation of overseas investment is not intended to control the scope and direction of this investment, but to strengthen "macroeconomic guidance". This is, it says, needed because Chinese enterprises have only been taking part in international competition for a short time and lack experience. As a result, there is a certain amount of "blindness and disorderliness in the overseas investment process". The Chinese government therefore has to strengthen oversight and planning and perfect relevant policies and laws, and ensure that overseas investment projects comply with laws, regulations and policies,

In March 2011 the threshold for examination and approval of large overseas investment projects in the natural resources category was raised from USD 30 million to USD 300 million, while the threshold for examination and approval of other categories of large overseas investment projects was raised from USD 10 million to USD 100 million. Key state-owned enterprises can now just file their overseas investments without having to submit them for examination and approval. ${ }^{113}$

The majority of China's OFDI is from state-owned enterprises (SOEs). Since a main focus of the "go global" strategy is to build national champions and these are mainly SOEs, SOE dominance is likely to continue. Nowadays, various top policy-makers in the Communist Party of China tend to

\footnotetext{
${ }^{110}$ NDRC, Report on the Implementation of the 2010 Plan for National Economic and Social Development and on the 2011 Draft Plan for National Economic and Social Development, Xinhua Net, 5 March 2011.

${ }^{111}$ Xinhua News Agency report, 7 March 2011 retrieved from www.news.cn.

${ }^{112}$ Ibid.

${ }^{113}$ Official news report, retrieved from http://www.jrj.com.cn/.
} 
have come up through, and/or have strong links to, the largest SOEs. ${ }^{114}$ However, Chinese leaders are also concerned to promote OFDI by private enterprises and individuals, both to increase the outflow of Chinese capital from private sources (since the government cannot use its reserves for direct investment abroad) and also to reduce uncontrolled outflows through alternative financial institutions.

One indication of a currently evolving policy of promoting such OFDI is a short-lived pilot project in Wenzhou, the relatively prosperous town on China's south-east coast which has been a disproportionately large source of emigrants for many years. In January 2011, Wenzhou Municipality announced that it was allowing individuals to conduct direct investment abroad on an experimental basis. This arrangement allowed individual investors to establish enterprises in the form of greenfield projects, M\&As or equity participation up to a limit of USD200 million, though this investment was not allowed to be in the stock or property markets. This pilot scheme appears to have been put in abeyance in February 2011 because it was alleged by the local foreign affairs bureau that it had not completed the proper procedures. ${ }^{115}$

It is normal for potentially controversial policies - like the establishment of Special Economic Zones at the beginning of the reform period - to be piloted in an appropriate locality before being spread to the rest of the country. It may well be that individual private OFDI is considered premature but that it will be allowed in the not-too-distant future. One indication of this is a speech by former Deputy Governor of the People's Bank of China Su Ning on 5 March 2011 in which he recommended the gradual relaxation of restrictions on individuals investing or purchasing assets abroad. ${ }^{116}$

\section{Risk forecasting and avoidance is becoming an important feature of China's outward investment}

The emphasis in OFDI policies is increasingly on risk reduction rather than merely on various forms of encouragement and targeting, while avoiding excessive interventionism: the key policy slogan is "government guidance, enterprise decision-making". New rules for risk avoidance appear to have been hurriedly devised during the "Arab spring" in the first half of 2011, when Chinese enterprises and workers in Libya and other countries had to make a rapid exit at a time of heightened uncertainty and actual or potential civil conflict. The government aims to study the risk situation in each host country and communicate early warnings to enterprises and then work out how to guard against risks once they have been discovered. It is also establishing and perfecting an emergency response mechanism. ${ }^{117}$

Different institutions are involved in providing financial and commercial support to the Go Global policy. These include policy-making bodies (MOFCOM and the National Development and Reform Commission), banks and insurance companies.

\footnotetext{
${ }^{114}$ See, for example, Li (2011).

115 Yuan, Ma, “Wenzho’s Overseas Investment Trial Halted”, Caixin Online, 24 January 2011: http://english.caixin.com.

${ }^{116}$ Ibid.

${ }^{117}$ Ibid.
} 
China's "go global" policy is administered by the Department of Outward Investment and Economic Co-operation (formerly the Department of Foreign Trade and Economic Cooperation) of MOFCOM, whose remit includes outward investment, overseas processing trade and $R \& D$, overseas resources co-operation, foreign engineering contracting, and labour service co-operation, including the employment of Chinese citizens overseas. Treaties covering China's outward FDI are negotiated by MOFCOM's Department of Treaty and Law. It also approves, monitors and manages enterprises engaged in outward investment, excluding financial services; formulates and implements standards on the qualification of domestic enterprises engaged in outward investment. The Department monitors China's outward FDI in terms of both quantity and quality: it is responsible for establishing and implementing a statistical system on outward FDI and for formulating and implementing performance evaluations and annual inspections of outward investments. ${ }^{118}$

As described above and in the 2008 Review, the approval process is being gradually streamlined to reduce obstacles to "going global". MOFCOM has played a major role, along with other ministries (such as the Ministry of Foreign Affairs) in developing "guidance catalogues" indicating promising sectors for investment by Chinese companies in various world regions. ${ }^{119}$ The Chinese version of MOFCOM's FDI website contains practical advice for investors in various countries. ${ }^{120}$

The Department of Outward Investment and Economic Co-operation is also charged with guiding, organizing and coordinating the construction of overseas economic co-operation areas. ${ }^{121}$ As explained below, China's provincial governments appear to be taking the initiative in setting up zones of this kind in other countries where their enterprises can benefit from positive externalities from infrastructure construction, joint publicity and so on, but such activities presumably also need to be agreed at state-to-state level. The distribution of responsibilities between China's central and local governments in this area remains to be determined.

\section{National Development and Reform Commission (NDRC)}

The National Development and Reform Commission (NDRC), which has evolved from the allpowerful State Planning Commission, is the other major government body responsible for implementing China's "go global" policy. The NDRC is a super-ministry which is, like the ministries, a member of the State Council, China's cabinet. It is responsible for international capital flows, foreign capital utilisation and outward investment, as well as for strategic planning to bring about an overall balance between foreign capital utilisation and overseas investment. The NDRC has approval powers for major projects on behalf of the State Council. While it is clear that investors apply in the

\footnotetext{
${ }^{118}$ MOFCOM website: http://hzs2.mofcom.gov.cn/.

${ }^{119}$ OECD (2008), p. 85 and footnote 36 on p. 121.

${ }^{120}$ Invest in China website: www.fdi.gov.cn.

${ }^{121}$ MOFCOM website: http://hzs2.mofcom.gov.cn/.
} 
first instance to MOFCOM for project approvals, it remains to be determined if (and if so, how far) the responsibilities of the NDRC and MOFCOM overlap.

\section{China Export and Import Bank (Eximbank)}

The most powerful tools in promoting OFDI are financial incentives provided by the government, as pointed out in the 2008 OECD Investment Policy Review of China. ${ }^{122}$ (OECD 2008). Chinese enterprises on the priority list can benefit from the government's financial support in the form of access to below-market rate loans, direct capital contribution, and subsidies associated with the official aid programmes. Eximbank and China Development Bank (CDB) are major providers of these financial incentives.

Among a host of deals announced involving Eximbank financing in 2010 were a USD900m agreement to fund railway and other projects in Nigeria, a USD300m deal to build a power plant in Vietnam, more than USD400m for e-government and water supply projects in Ghana, and a USD1.7bn loan to build a hydropower plant in Ecuador, its second such project in the country. ${ }^{123}$ Some of the largest loans in 2011 went to Pakistan (USD1.7b to develop a city-wide train system in the eastern city of Lahore), ${ }^{124}$ Ethiopia (USD400m for the implementation of various projects planned under the five-year Growth and Transformation Plan), ${ }^{125}$ and Russia's En+ Group (USD5b to finance the construction of thermal and hydro power plants, the development of coal fields and iron ore mining as well as copper concentration projects in Eastern Siberia). ${ }^{126}$

\section{China Development Bank (CDB)}

According to $\mathrm{CDB}$ representatives, its primary role is to provide finance to enable China to invest in natural resources abroad to meet its domestic needs (which they call the "blue sea strategy"). The CDB's financial support is not, though, limited to overseas investments in natural resources. The CDB's lending to support overseas investments is also motivated by a search for good customers after the $\mathrm{CDB}$ found there to be a shortage of good customers and too many financial institutions competing for business in the domestic market, viewed by the CDB as a "red sea". By 2010, the CDB had over 140 work teams around the world, some of them expanded into branches or representative offices and was engaged in large international energy projects in Russia, Brazil, Venezuela, Indonesia and Turkmenistan. According to that latest information on its website, by end-2009, the CDB's

\footnotetext{
${ }^{122}$ OECD (2008), p.90.

${ }^{123}$ EIU Viewswire, 14 March 2011.

124 “China Eximbank to lend Pak \$1.7bn for train system”, Dawn, 28 April 2011.

${ }^{125} \mathrm{http} / / /$ danielberhane.wordpress.com/2011/12/06/ethiopia-chinas-exim-bank-sign-6-9-bln-birr-loan-agreements.

${ }^{126}$ http://www.chinadaily.com.cn/bizchina/2011-06/17/content_12720146.htm.
} 
international businesses covered 78 countries, with outstanding balances in foreign currencies reaching USD97.4 billion. ${ }^{127}$

\section{Industrial and Commercial Bank of China (ICBC)}

ICBC, the largest bank in China, supports outward FDI through its rapidly expanding global network. In August 2008, ICBC became the second Chinese bank since 1991 to gain federal approval to establish a branch in New York City. By end-June 2011 it had 220 overseas subsidiaries in 29 countries and regions and a global network of 1,516 correspondent banks in 134 countries and regions, while its aggregate assets in overseas subsidiaries exceeded USD 100 billion. ${ }^{128}$

ICBC provides investment banking services and financial support to Chinese corporations for both acquisitions and greenfield projects overseas. In the first half of 2011, ICBC supported the Wuhan Iron \& Steel Group's acquisition of an iron mine in Madagascar. ${ }^{129}$ In July 2011 ICBC extended a USD 500 million loan to finance construction of the Gibe 3 Dam in Ethiopia. ${ }^{130}$

ICBC is also a major outward investor in its own right; for example, in 2007 it acquired a $20 \%$ stake in South Africa Standard Bank for USD 5.6 billion. ${ }^{131}$

\section{China Export \& Credit Insurance Corporation (Sinosure)}

Since 2001, Sinosure has been providing insurance cover not only for exports but also for investments. This cover provides a risk guarantee against economic losses resulting from war, currency exchange bans, requisitions and breach of contract by host country governments. It includes both equity and liability insurance. In 2010, Sinosure's investment and leasing insurance reached USD 14.2 billion and Sinosure helped enterprises obtain USD 250 billion in bank financing. ${ }^{132}$

\section{OFDI by provincial-level units varies widely}

As is the case with inward FDI, there is a wide range of distribution in OFDI between provinces, with richer coastal urban provinces and municipalities in the Eastern region reporting much larger OFDI stocks than provinces and autonomous regions in the Central and Western regions. By end-2010 Zhejiang was the largest provider of outward FDI, accounting for $17 \%$ of the national total. Clustered not far behind were Liaoning (12.3\%, mostly from the port city of Dalian), Shandong (12\%), Guangdong (10.1\%) and Shanghai (10\%). The smallest provider was the western province of Qinghai,

\footnotetext{
${ }^{127}$ PowerPoint presentation “CDB Go Global, Denmark Project 2010" retrieved at http://gdex.dk/ofdi10/Presentations/about\%20CDB.pdf.

${ }^{128}$ ICBC website: http://www.icbc.com.cn.

${ }^{129}$ ICBC website: http://www.icbc.com.cn.

130 "ICBC quiet over controversial dam project", South China Morning Post, 2 June 2011.

${ }^{131}$ Davies (2010b). At end-2011, Standard Bank had a market capitalization of USD20bn.

${ }^{132}$ Sinosure website: http://www.sinosure.com.cn.
} 
not registering in percentage terms with its insignificant USD 1.4 million, and Tibet was not included in the official listing so presumably had registered no outward investments by the end of $2010 .{ }^{133}$

\section{Divergent local policies towards outward FDI are starting to become apparent}

Local authorities such as provinces and municipalities have for three decades had an incentive to publicise their policies towards inward FDI: since these largely consisted of improvements in the investment environment, fiscal incentives and other sweeteners such as free or cheap land provision, such publicity was a relatively low-cost and easy form of investment promotion. Brochures outlining these local policies were printed out and handed to visiting potential investors and later put on provincial investment promotion agency (IPA) websites.

By contrast, local policies towards outward FDI have been, if not exactly secret, largely confidential. There is no investment promotion benefit from publishing such policies, and provinces might not be particularly keen for their neighbouring competitor provinces to be aware of what they are doing to encourage enterprises under their administration to "go global". Public opinion may also misinterpret outward FDI as a form of hollowing out. The Chinese government states that local administrations carry out the central government policies on outward investment in a unified way, while at the same time making appropriate arrangements in accordance with local conditions, and that these policies are open and transparent. Nevertheless, some provinces and municipalities seem to be more open than others in providing information about their overseas investment policies (see below).

Therefore, while the Ministry of Commerce has in recent years published reports on China's national outward FDI performance and policies, these - and the Ministry's FDI website - have been largely silent on the nature of and differences between local government policies towards outward FDI. This situation improved in 2010 with the publication of an annual report (which is of high quality, though so far published only in Chinese) which includes information on the outward FDI situation in 11 provinces and major cities. ${ }^{134}$ It is normal practice in such yearbooks to include reports on all 31 provincial-level units. The fact that this report only covers just over one-third of these units suggests that the central government itself has not found it easy to gather data and policy statements from local governments in this area of their work. The format of the reports suggests that they may have been responses to a questionnaire.

The picture that emerges from this incomplete information is one of divergence between localities in both "go global" policy and outward FDI performance and increasing co-ordination between outward-investing enterprises at provincial level.

\section{First-movers were the coastal cities and provinces, --}

Coastal cities and provinces started encouraging outward investments right at the beginning of the economic reform period in the late 1970s and the beginning of the 1980s. At that time, the

\footnotetext{
${ }^{133}$ MOFCOM (2011).

${ }^{134}$ Ministry of Commerce of the People's Republic of China (MOFCOM) (2010b).
} 
emphasis of government policy was on attracting inward FDI, so there appears to have been no coordinated outward investment strategy resulting from concerted policy discussions between the provinces themselves or between provinces and the central government. Instead, is investment appears from the examples in the next paragraph to have been the result of local initiatives taken at different times. Most are one-off, relatively small investments:

- Beijing: OFDI began with a joint venture cuisine company in Japan set up by the Beijing Municipality Friendship Commercial Services Corporation in November 1979. ${ }^{135}$

- Shanghai's first non-trade overseas enterprise, Baromon Tailoring in Hong Kong, China, was set up in 1981, while Shanghai's first foreign investment project in manufacturing was a joint venture knitted garment factory in Mauritius established in June 1986 by Shanghai Overseas Economy Group, Shanghai Knitted Garment Group and a Hong Kong (China) investor. $^{136}$

- OFDI from Jiangsu province (next to Shanghai) was relatively small-scale in the 1980s, with the 76 enterprises approved to operate overseas investing only USD20 million abroad in total, $91 \%$ of it related to trade expansion, before picking up in the following decade. ${ }^{137}$

- $\quad$ OFDI from Zhejiang began in 1982, non-trade-related OFDI in $1985 .^{138}$

- The first OFDI from Shandong occurred in 1978 when the Shandong Province Foreign Trade Corporation set up the Lu Xing Enterprise Company Limited in New York. ${ }^{139}$

- The first outward investment from Fujian, the coastal province adjoining Guangdong and home to one of the first Special Economic Zones, was the Jiaming Development Company Limited in Hong Kong (China), a joint venture between a Fujian foreign trade enterprise and a local investor in 1979. ${ }^{140}$

- Guangdong, next to Hong Kong (China), with most of the country's Special Economic Zones and at that time the main recipient of inward FDI, also set up its first outward

\footnotetext{
${ }^{135}$ Information on Beijing in this section is from the report by the Beijing Municipal Commerce Commission in MOFCOM (2010b).

${ }^{136}$ Information on Shanghai in this section is from the report by Shanghai Municipal Commerce Commission in MOFCOM (2010b).

${ }^{137}$ Information on Jiangsu in this section is from the report by Jiangsu Province Commerce Bureau in MOFCOM (2010b).

${ }^{138}$ Information on Zhejiang in this section is from the report by Zhejiang Province Commerce Bureau in MOFCOM (2010b).

${ }^{139}$ Information on Shandong in this section is from the report by Shandong Province Commerce Bureau in MOFCOM (2010b).

${ }^{140}$ Information on Fujian in this section is from the report by Fujian Province Foreign Trade and Economic Co-operation Office in MOFCOM (2010b).
} 
investment in Hong Kong (China) in the 1980s: the Olympian Enterprise Group Company Limited. ${ }^{141}$

Following these small beginnings in the 1980s, major local initiatives appear to have begun in the more developed coastal region in the 1990s at the behest of the central government, starting with a big push in the Shanghai region. Although Shanghai had developed economically along with the rest of the country in the first decade of the reform period, it had not pioneered open and creative policies to attract foreign investment as vigorously as Guangdong, where the first Special Economic Zones had been established in 1980. It was not until the early 1990s that the central government decided to make Shanghai a major centre of economic development and reform (the "head of the dragon", ${ }^{142}$ in the words of paramount leader Deng Xiaoping in 1992). These measures appear to have given Shanghai a head of steam in its outward investment strategy that has been followed up actively after the announcement of the "go global" policy.

In 1992 the then Ministry of Foreign Economic Relations and Trade (a predecessor of MOFCOM $^{143}$ ) approved foreign economic activities for a number of large, well-established enterprises in Shanghai, including Shanghai Electric (Group) Corporation, Shanghai Hydroelectric Power (Group) Corporation, East China Construction Design Research Institute Limited and Shanghai Light Industry Design Institute Limited. An active policy of promoting OFDI from Shanghai began in earnest in 2001 with a set of regulations that included a Guiding Opinion on Accelerating the Implementation by Shanghai of the "Go Global" Strategy and Administration Rules for Private Enterprises Bidding for Overseas Enterprises. In 2004 the Shanghai Municipal Government promulgated Some Opinions Concerning the Further Promotion of the "Go Global" Strategy and this was followed in 2005 by a three-year plan, the Programme of Action to Encourage Enterprises to Implement the "Go Global" Strategy (2005-2007). A strategic forum and a municipal conference brought together the whole municipality to discuss which key countries and territories to target in Shanghai's "go global" effort.

Fujian also seems to have been an important focus of pre-"go global" local-government-promoted OFDI activity in the 1990s, but not to the same extent as Shanghai.

During the exploratory phase of Fujian's OFDI in 1987-1992, some SOEs and units engaged in foreign affairs set up wholly-Chinese-owned, joint venture and co-operative enterprises in Hong Kong (China), Macau (China) and overseas to expand the province's trade and other international economic activities. In the readjustment phase (1993-2000) there was uninterrupted growth in the number of

\footnotetext{
${ }^{141}$ Information on Guangdong in this section is from the report by Guangdong Province Foreign Trade and Economic Cooperation Office in MOFCOM (2010b).

${ }^{142} \mathrm{Li}(2009)$

${ }^{143}$ The Ministry of Trade established in 1949 at the inception of the People's Republic of China, has undergone several name changes: Ministry of Foreign Trade (1952), Ministry of Foreign Economic Relations and Trade (MOFERT, 1982), Ministry of Foreign Trade and Economic Cooperation (MOFTEC, 1993) and Ministry of Commerce (MOFCOM, 2003). The 1982 and 2003 name changes also accompanied the incorporation of other government bodies into the ministry.
} 
production investment projects overseas but because of the national policy of tidying up and rectification of OFDI, the speed of development was slow.

\section{-- with hinterland provinces following some years later}

Landlocked and poorer hinterland provinces such as Hunan and Xinjiang did not really start making outward investments until after the "go global" policy was announced in the early 2000s.

Hunan does not report significant OFDI before 2000. In January 2000 the Xiangtan Divine Dragon Industrial Company Limited received approval from the then Ministry of Trade and Economic Co-operation to invest USD1 million to set up the Star Bedding Company in Algiers - the first overseas investment by a Hunan company. In 2001, the Heavy Industry Development Company Limited of Changsha acquired Paul McNair in the UK - Hunan's first overseas M\&A transaction. ${ }^{144}$

Further south, Yunnan does not seem to have started "going global" before 2003 despite its proximity to China's South East Asian neighbours, which had already attracted OFDI from other parts of China. ${ }^{145}$

\section{Coastal provinces have continued to lead OFDI}

The coastal provinces have continued to record much larger OFDI stocks and flows than their inland counterparts following the inception of the "go global" policy. This may be in part because they had a head start and also because the factors that stimulated and facilitated that head start have continued to operate.

From 1979 to 2009 Beijing Municipality authorised 907 enterprises to invest in 95 countries and territories, with the Chinese side's authorised investment totalling USD3,030 million. Beijing's OFDI stock reached USD3,760 million by end-2009. ${ }^{146}$ In 2009 Beijing's total OFDI flow involving 140 enterprises was USD450 million, a rise year-on-year of 35.9\%.

From 1979 to 2009, 803 firms in Liaoning Province in North East China were authorised to make a total of USD2,850 million in OFDI, USD2,310 million of this being Chinese-side investment. MOFCOM statistics show Liaoning's OFDI stock to have been USD1.5 billion with completed turnover of USD6.5 billion at the end of 2009. Since 2000, Liaoning's cumulative authorised Chineseside investment abroad has been growing at an average annual rate of $49.1 \%{ }^{147}$

By end-2009 Shanghai had accumulated OFDI stock of USD3.6 billion, and a cumulative USD5.4 billion (of which USD4.9 billion was invested by the Chinese side) in 828 authorised OFDI

\footnotetext{
${ }^{144}$ Information on Hunan in this section is from the report by Hunan Province Commerce Bureau in MOFCOM (2010b).

${ }^{145}$ Information on Yunnan in this section is from the report by Yunnan Province Commerce Bureau in MOFCOM (2010b).

${ }^{146}$ Report of the Beijing Commerce Commission in MOFCOM (2010b).

${ }^{147}$ Information on Liaoning in this section is from the report by the Liaoning Province Foreign Trade and Economic Cooperation Office in MOFCOM (2010b).
} 
projects, in 101 countries and territories. Several large Shanghai enterprises have established a major presence abroad, like Shanghai Electric (Group) Corporation. Despite the global economic crisis, Shanghai's approved OFDI rose 117\% year-on-year in 2009 to reach USD1.5 billion (nearly all Chinese-side investment) in 249 projects, including 20 key projects each with an investment of over USD10 million by Shanghai enterprises and accounting for 70\% of Shanghai's OFDI in that year. In 1991-2000, Chinese-side investment of USD123 million was approved.

Approved OFDI in Jiangsu in 1992-1993 alone was greater than that in the whole period 19801990. It then declined to a trough in 1994-1995 before rising to a peak value in 1996. In 2001-2009 Jiangsu's OFDI accelerated rapidly, with 1,286 firms approved to invest USD2.9 billion in Chineseside OFDI - over 20 times total cumulated Chinese-side OFDI before 2000. Approved OFDI from Jiangsu broke through USD100 million in 2004 and then through USD1 billion in 2009. In the 2000s, average approved Chinese-side OFDI per project was USD2.2 million, 5.9 times that in the 1990s. Of these, 55 projects had approved Chinese-side OFDI of over USD10 million, totalling USD1,350 million. In 2009, the OFDI outflow from Jiangsu Province reached USD850 million, a year-on-year increase of $72.2 \%$, involving 332 enterprises with approved OFDI, a year-on-year increase of $43.1 \%$. Approved Chinese-side OFDI for the first time broke through USD1 billion, rising year-on-year by $67.6 \%$. Large-scale outward investments are on the increase. In 2009 there were 72 OFDI projects with approved Chinese-side investment exceeding USD5 million, more than double the year before, and these summed to USD850 million, $80.3 \%$ of the provincial OFDI total; 26 of these projects were larger than USD10 million, nearly twice as many as the year before.

In 2000-2009 the number of approved OFDI projects from Zhejiang rose from 107 to 475, cumulatively totalling 3,336, while accumulated approved Chinese-side OFDI increased from USD16 million to USD1.2 billion, an annual average increase of 54.6\%. Average investment per project went up from USD148,000 to USD1.4 million. In 2009, Zhejiang's OFDI reached USD700 million, 81.1\% up year-on-year. Altogether 475 firms were approved to invest overseas with approved Chinese-side investment totalling USD1.2 billion, an increase of $43.5 \%$ over 2008 and greater than all the province's OFDI in the Tenth Five-Year Plan period put together.

Fujian's OFDI continued in the most recent phase from 2001 onward, based on private-sector OFDI, so that by end-2009 Fujian Province's cumulative OFDI stock reached USD1.6 billion, with approved Chinese-side investment by 885 enterprises reaching USD1.2 billion. Fujian's OFDI projects are becoming larger: in 2009, average approved OFDI per project was USD2.6 million, 1.5 times the historical cumulative average before that year. Among these was a group of investments exceeding USD10 million each, including by China Wuyi Company Limited, Fu Yao Glass Industry Group, the Fujian New World Technology Group, Fujian Jiuzhou Perimeter Economic Development Company Limited, the Fuzhou Hong Long Sea Food Company Limited and the Fujian You Tuo Trading Company Limited. In 2009 Fujian Province's OFDI flow reached USD370 million, an increase of $126.2 \%$ over 2008. Newly-approved OFDI (including increases in capital) by 165 enterprises reached USD490 million (up 64\% year-on-year), of which Chinese-side investment totalled USD440 million (up 75\% year-on-year). Of these enterprises, 20 had Chinese-side investments exceeding USD5 million, totalling USD225 million, 51.6\% of the total. Fujian's OFDI is concentrated mainly in three port cities. In 2009, 128 of the provincial total of 165 outward-investing enterprises (i.e. 77.6\%) were located in Fuzhou, Xiamen and Quanzhou. 
Shandong -- during the Sixth and Seventh Five-Year Plan Periods (i.e. 1981-1990) 47 firms conducted OFDI with a total approved Chinese-side value of only USD15 million. During the Eighth and Ninth Five-Year Plan periods (1991-2000) OFDI expanded to an approved Chinese-side investment value of USD345 million by 566 firms, mainly in the form of overseas trading companies or offices established by provincial-level foreign trade corporations. During the Tenth Five-Year Plan period (2001-2005), Shandong's OFDI developed rapidly, with approved Chinese-side outward investment by 537 firms reaching USD740 million, over double the amount in the previous two FiveYear Plan periods combined. OFDI accelerated in 2006-2009, with approved Chinese-side investment by 936 firms reaching USD2.6 billion. In 2009 Shandong's OFDI reached USD1.1 billion in terms of approved Chinese-side investment by 299 firms, 67.6\% higher than in 2008, while actually utilised OFDI was USD700 million, up 48.4\% year-on-year. 22 projects exceeded USD10 million, while average project investment size was USD3.8 million, an increase of over USD1 million on the year before.

At end-2009 Guangdong had established 2,378 overseas enterprises in over 100 countries and territories with total approved Chinese-side investment of USD9 billion. MOFCOM statistics show Guangdong's end-2009 OFDI stock as having reached USD10 billion. In 2009 Guangdong's OFDI reached USD920 million, 9.7\% of the national total. That year, 356 firms obtained approval to make new outward investments, while 49 added capital, making a combined total of USD1.4 billion in approved Chinese-side OFDI.A notable feature of this OFDI is the predominance of large projects. Average approved project size was USD3.2 million, with 19 projects exceeding USD10 million and totalling USD823 million, equivalent to over half that year's overall OFDI, while there were 55 projects between USD5 million and USD 10 million with a combined value of USD423 million, $28.3 \%$ of the year's overall OFDI.

In 2006-2009 Hunan's large-scale enterprises accelerated their "go global" activities with many M\&A deals, including Hunan Nonferrous Metals Holding Group Company Limited's acquisition in Perth, Australia, Zoomlion's acquisition of the Italian company CIFA, and Hunan Valin Iron and Steel Group Company Limited's acquisition of FMG in Australia. In 2007 Hunan's actually realized OFDI reached USD140 million investment in 2008, USD250 million in 2008, and USD1 billion in 2009. By end-2009, approved cumulated Chinese-side investment in Hunan Province was USD2.4 billion. MOFCOM statistics record Hunan's end-2009 OFDI stock as USD2 billion. In 2009 Hunan's OFDI outflow reached USD1 billion, nearly three times the year before. Approved OFDI by 94 firms totalled USD5.3 billion, a tenfold increase on 2008. Of this, USD1.2 billion was Chinese-side approved OFDI, five times the year before and more than all the previous Chinese-side investment combined.

Yunnan's OFDI flow in 2009 reached USD270 million from 65 enterprises with approval to invest USD500 million abroad, an increase of 20.9\% over the previous year. By end-2009 Yunnan's OFDI stock had reached USD950 million, of which USD740 million had been accumulated during 2005-2009. At the initial stage, in the 1990s, Xinjiang's OFDI took the form of a few small-scale trade-related enterprises with an average investment per project of less than USD50,000. In 1993 there was a total of over 150 OFDI projects, but the total investment in these did not reach USD2 million. In 2009 Xinjiang's OFDI flow reached USD180 million, an increase of $160 \%$ over the year before. Its OFDI stock totalled USD520 million at end-2009. 
In the 2000s, Xinjiang, the huge westernmost provincial-level unit (its full name is Xinjiang Uygur Autonomous Zone), has chosen to target the natural resources area as its breakthrough point for "going global" and Central Asia as the main destination. Before 2002 there were over 200 Xinjiang firms approved to invest abroad, but not many of these were really in a position to engage in regular production with a service life of over five years. Average OFDI project size was USD100,000, while OFDI was mostly concentrated in trade. ${ }^{148}$

\section{The direction of outward FDI has varied between provinces, --}

The target host countries and territories vary widely between provincial-level units. This is partly because of proximity, for example Xinjiang's position next to Central Asia, but probably more because of the variation in access to world markets resulting from being positioned on the coast or inland and also from wealth differences. Because sizeable waves of emigration from China in earlier periods, another important factor is the status of some provinces is their connection with their diasporas in such places as South East Asia and North America.

Beijing is an example of a prosperous city near China's coast which has had the capacity to export capital all over the world and, as the capital city and a major financial centre, has also invested abroad on behalf of national enterprises. Hong Kong, China, the United States, Korea, Peru, the British Virgin Islands and the United Kingdom each received more than USD100 million in OFDI from Beijing. Asia received the highest proportion of Beijing OFDI, 46.7\%, with $21.1 \%$ going to North America, $11.1 \%$ to Europe, $9.2 \%$ to Oceania, $6.1 \%$ to Africa and 5.8\% to South America. In 2009 Asia remained the main target, absorbing 48.2\%, North America taking 11.9\%, Latin America $30.4 \%$, Africa $7.1 \%$ and Oceania 2.5\%. The proportion of Chinese-side investment was $79 \%$ of the total and was on a rising trend.

The other major center with a coastal and wealth advantage is Shanghai, which is also the corporate headquarters of many national enterprises. However, Shanghai's OFDI is reported by the local authorities as being concentrated in Asia, though as this statement is not accompanied by any figures it remains to be determined to what extent this is the case.

Jiangsu's OFDI is clearly concentrated in Asia: in 2009, 186 new projects (56\% of all projects) were approved in Asia with Chinese-side OFDI total value of US650 million, 61.6\% of the global value of Jiangsu's OFDI. The largest recipient of the province's OFDI was Hong Kong (China).

Zhejiang's OFDI is also mainly concentrated in Asia (50.9\% of projects, $65.8 \%$ of OFDI), Europe (17.9\% of projects, $10.6 \%$ of OFDI) and North America (17.7\% of projects, $10.6 \%$ of OFDI).

Fujian's OFDI is becoming more geographically diverse, expanding from Hong Kong (China) and Macau (China) to trading enterprises and processing nodes in South East Asia, Latin America, Africa and Europe; the number of countries and territories with Fujian investment has grown from 42

\footnotetext{
${ }^{148}$ Information on Xinjiang in this section is from the report by Xinjiang Uygur Autonomous Region Commerce Bureau in MOFCOM (2010b).
} 
to 65. Not surprisingly, as Fujian is located directly opposite Chinese Taipei (whose inhabitants originate in large part from Fujian and speak Fujianese), Fujian enterprises are starting to break through into the Chinese Taipei market. Fujian New World Computer Company Limited has become the first Chinese mainland company approved to invest in an enterprise in Taiwan. The key locations of Fujian's OFDI are Hong Kong (China) and the United States. In 2009 newly-approved Chinese-side OFDI in Hong Kong (China) by 54 enterprises reached USD226 million (including capital increases), $52 \%$ of total FDI, while OFDI in the United States by 19 enterprises reached USD37 million.

Shandong's OFDI is also expanding to more markets. There are 168 recently-established enterprises in Asia with Chinese-side investment of USD540 million, 48\% of total provincial OFDI. Chinese-side OFDI from Shandong has broken through the USD100 million mark in Africa, North America and Europe, while enterprises have been established for the first time in Syria, Liberia and Libya. The province is now involved in OFDI in 126 countries and territories.

Hunan's OFDI goes to some 50 countries and territories. The main destinations are the ASEAN countries, Hong Kong (China), the United States, Germany, Italy, Sweden, the Netherlands, Australia, Congo (DRC), Algeria and Nigeria.

By far the largest destination for Guangdong's OFDI is neighbouring Hong Kong (China), with $65.7 \%$ of the total. Other destinations include Asia (excluding Hong Kong (China)) with 10.8\%, North America (17\%), Africa (3.6\%), Europe (2.1\%), South America (0.7\%) and Oceania (0.3\%).

Yunnan clearly now takes advantage of its regional location by investing first in Burma, Lao PDR and Vietnam, which are the main destinations for its OFDI and is also spreading its OFDI more widely to developed countries like the United States.

\section{—as has its sectoral composition}

The sectoral distribution and degree of diversification has varied between the various provinciallevel units.

Beijing OFDI has become diversified across primary, secondary and tertiary industries. In the period 2005-2009, Chinese-side authorised investment in leasing and financial services accounted for $31 \%$ of Beijing's total Chinese-side authorized investment overseas, while such investment in manufacturing comprised $16 \%$, mining $15 \%$ and ICT $9 \%$.

In Shanghai, the most active push is into manufacturing and commercial services OFDI.

Jiangsu's OFDI was mainly concentrated in manufacturing, mining and commercial services.

Most of Zhejiang's OFDI in 2009 was in textiles (21.1\% of the number of projects, $27.5 \%$ of approved Chinese-side FDI), machinery (15.6\% of projects, $11 \%$ of OFDI) and electronics $(7.4 \%$ of projects, $6.7 \%$ of OFDI).

Investments from Fujian have developed from single to diversified in nature. To begin with, investments were trade-led, taking the form of an expansion of existing trade networks overseas. By 
end-2009, 448 Fujian enterprises had set up overseas trading network nodes in Hong Kong (China) and elsewhere, accounting for $47.8 \%$ of the number of OFDI projects. Enterprises established specialist sales points to promote their brands so as to develop from exporting products to exporting brands. Processing trade has become Fujian's main form of production investment overseas, involving exports of raw materials, equipment and semi-finished products. Before 2004, Fujian had no OFDI in natural resources. In 2005-2009, actually utilised Chinese-side overseas investment by 31 Fujian enterprises in natural resource exploitation totalled USD1.9 billion; these investments included gold, copper and molybdenum prospecting and mining and fisheries. Fujian Far Ocean Fisheries (Group) Corporation has invested in fishing and fish processing in Indonesia.

Manufacturing has become particularly important in Shandong's OFDI, cumulatively totalling USD1.1 billion $31 \%$ of the provincial total. Most of this is in textiles, apparel, household electronic appliances, iron and steel, agricultural machinery and leather. Shandong has also been involved in joint resource exploitation overseas, with firms investing a cumulative approved Chinese-side total of USD970 million in 117 projects in coal, iron ore, gold, bauxite, lead and zinc mining, timber and natural rubber. In 2004 China's first "go global" coal investment occurred when Yanzhou Coal Company Limited invested AUD32 million to buy a stake in the Oster coal mine in Australia. In 2009 Yanzhou purchased Felix Resources Limited, also in Australia, for AUD3.3 billion. Shandong's OFDI is becoming more diverse. In 2009 manufacturing OFDI reached USD210 million, 20\% of the total, while prospecting and mining totalled USD190 million, 19\% of the total. Trade and services together made up USD330 million, 30\% of the total. OFDI in agriculture was recorded at USD196 million.

The sectors involved in Hunan's OFDI include mining and natural resource exploitation, import and export trade, metallurgy and machinery, motorcycle production, assembly and component marketing, construction materials, engineering equipment products and rail product manufacture and marketing and wind turbine technology development.

The main areas of Yunnan's investment are hydroelectric power and agriculture. To address the challenge of development in Central Asia, Xinjiang enterprises chose to initiate investment abroad in renovating old enterprises as the breakthrough point. Because of the break-up of the former Soviet Union, many old enterprises in Central Asia suffered from a break in the production chain that resulted in many of them going bankrupt or ceasing production, putting pressure on local finance and employment. By acquiring these old enterprises and restoring their productive capacity, Xinjiang enterprises helped solve local economic development and employment problems while also helping develop their overseas investment. OFDI is mainly concentrated in: acquisitions of natural resources, especially mineral and forestry resources; acquisitions of high-end marketing channels; and investment in downstream processing links, mainly in co-ordination with setting up supply chains for upstream projects.

\section{Greenfield investments have been important, but M\&A FDI is increasing}

While a number of important greenfield investments have been reported, an important feature of China's outward FDI is a trend towards more acquisitions of companies in host countries. 
Cross-border M\&As are beginning to emerge prominently in Liaoning's OFDI. Dalian Machine Tools Group Corporation (DMTG) purchased CM Systems from Ingersoll in the United States.

In Shanghai, M\&A deals stand out head and shoulders above other forms of OFDI. In 2009, Shanghai enterprises concluded 22 cross-border M\&A OFDI deals with approved investment capital of USD 690 million, equivalent to $45 \%$ of the municipal total. These included the acquisition of Goss International in the United States by Shanghai Electric.

So far, 38 enterprises with a total capital of USD3.5 billion have been established overseas by Shandong investors through M\&A. For example, Wanhua Industrial (Group) Company Limited grasped the opportunity by the financial crisis to purchase a $36 \%$ stake in the Hungarian company BorsodChem for EUR100 million. The larger companies in Shandong are conducting cross-border M\&As. In 2009, 23 firms invested a total of USD3.3 billion in overseas acquisitions, taking advantage of the economic crisis.

Hunan -- the 2009 figures showed a marked increase in overseas M\&A deals. Before 2008 there were only two such transactions. In 2008-2009 enterprises in Hunan completed 11 M\&As with total Chinese-side approved investment of USD1.2 billion. A notable feature in 2009 was the emergence of overseas M\&As, though the provincial authorities do not provide a quantitative estimate of its relative importance.

\section{The structure of China's foreign-invested enterprises differs between provinces}

The varying conditions of FDI from China's provinces and province-level municipalities have given rise to a diversification of structure. From 2001 onward, the forms of OFDI have been diversified, including equity joint ventures, contractual joint ventures, equity swaps and acquisitions by purchase.

Zhejiang's outward-investing entities in 2009 were mainly trading companies (49.5\% of projects, $33.2 \%$ of OFDI), economic and trade management offices (19.2\% of projects, $1.2 \%$ of OFDI), production enterprises (18.5\% of projects, $27.4 \%$ of OFDI), resource exploitation firms $(9.9 \%$ of OFDI), research and development institutions (1.1\% of OFDI) and processing trade $(5.2 \%$ of OFDI).

Guangdong's OFDI has steadily evolved from single-purpose trading companies to setting up overseas manufacturing bases, developing overseas co-operation in natural resources, setting up overseas research and development centres and marketing networks. For example, after GREE set up an air conditioning production base in Brazil, TCL and Midea accelerated their implementation of transnational management strategies, setting up production bases, marketing networks and research and development institutions overseas one after another. At the same time, overseas co-operation in natural resource exploitation has become a new area for Guangdong's OFDI. 


\section{Private-sector OFDI tends to predominate in coastal areas, state-sector OFDI in the interior}

Policies towards encouraging private-sector or public-sector OFDI diverge noticeably, largely in line with economic and geographical realities. Coastal provinces that already have sizeable privatesector outward FDI are encouraging more of the same.

The main driver of Beijing's OFDI has become private OFDI, which was over 70\% in 2009. There were projects in which Chinese-side OFDI was over USD5 million, accounting for $78 \%$ of Beijing's OFDI. In Shanghai, too, private enterprises continue to hold their position as an OFDI advance force.

Jiangsu's OFDI is mostly from the private sector. During these nine years, 787 private enterprises (61.2\% of all outward-investing enterprises in the province) had approved Chinese-side OFDI of USD1.9 billion, $65.8 \%$ of the provincial total. In 1982-1991 there were 51 approved OFDI projects with total Chinese-side investment of USD59 million, all of it by SOEs or government departments, mainly foreign-trade bodies. The predominance of SOEs continued in 1992-1999, when approved Chinese-side OFDI rose to USD220 million. Private OFDI began in 1998.

In 2001 the Zhejiang provincial government promulgated a strategic initiative for the whole province to "go global", explicitly basing this on private-sector OFDI. Private enterprises retain their dominant position: at end-2009, they accounted for $95 \%$ of the cumulated total of Zhejiang's OFDI projects.

Fujian -- trial investments by private investors in earlier periods have been expanded. In 20082009 some USD50 million, capital of around 20\% of total provincial OFDI, was added to existing projects. Among outward-investing enterprises, private-sector investors developed relatively rapidly. Up to end-2009 there were 260 enterprises established abroad with approved investment by Hunan's private enterprises totalling USD700 million, $11 \%$ of the provincial total private-sector OFDI was distributed across over 40 countries and territories.

Yunnan -- reliance is mainly on "central enterprises", i.e. major SOEs, which have the advantages of ample funds, management scale and advanced technology.

Interior provinces like Xinjiang appear to be mainly encouraging state-sector outward FDI. Coastal provinces tend to focus on global markets; Xinjiang understandably is promoting further cooperation with partners in Central Asia.

\section{Co-operation in OFDI among investors is common in most provinces}

One feature of local policy that appears to be common to most, possibly all, provincial-level units is a tendency to encourage investors to co-operate more with each other in investing in specific target host countries. The reports hint at excessive competition, overlaps and dissension between Chinese enterprises in individual host countries and recommend a more coordinated approach. 
Several localities encourage enterprises to invest together in special economic zones in host countries and even to participate themselves in constructing such zones. Enterprises can thus derive benefits from industrial clustering.

Jiangsu is starting to establish economic and trade co-operation zones overseas, for example six Jiangsu enterprises have invested in the Sihanoukville Special Economic Zone in Cambodia. By end2009 approved Chinese-side OFDI in the Eastern Industry Zone in Ethiopia had cumulated to USD14 million, half of which was accounted for by new projects in 2009 .

Much of Zhejiang's OFDI is in foreign economic and trade co-operation zones and industry parks overseas, where 50 firms have invested USD360 million. Provincial policy on encouraging enterprises to "go global" is focused on measures to promote OFDI, especially emphasising the role of private-sector OFDI as the main force and encouraging firms to flock together in "going global", especially by working together to establish economic zones overseas as a platform for their OFDI.

Fujian -- Formerly scattered OFDI projects are moving towards cluster development as officials encourage investors to set up trade processing and similar kinds of zones overseas so as to integrate resources, reap scale economies, avoid risks and diversify.

Foreign investment associations have been set up to strengthen protection of overseas investments and enhance the cohesion of Hunan enterprises, which have spontaneously established Hunan Chambers of Commerce in Laos, Thailand and the United Arab Emirates where they facilitate synergies and group development while also strengthen communication and exchanges between Hunan enterprises and local communities.

A number of provinces report that they are encouraging "going global" by setting up trading networks overseas that bring enterprises together in joint promotion exercises.

Zhejiang reports having successfully established such overseas marketing networks, promoting what it calls "dynamic exporting by independent brands". The number of such projects increased by $22.1 \%$ in 2009 .

Some success is being reported in setting up overseas trading networks by Fujian. In 2009 newly-approved Chinese-side OFDI by 95 enterprises reached USD184 million, 42.25 of total OFDI, promoting domestic exports of around USD300 million. This OFDI takes the form of "tailored" investment to enhance the global reputation of brands.

Hunan's enterprises are reported as regarding this as a unique approach to "going global". For example, Hunan's Sanyi Company Limited has set up manufacturing bases, after-sales service bases and investment companies in 18 countries and territories to develop local management and establish brand image.

\section{A major motivation of OFDI is technology acquisition}

An important reason for investing abroad - other than being required to implement a national "go global" policy - is technology acquisition. For example, in 2009, Beijing Automotive Industry 
Holding Company Limited purchased Saab intellectual property in a USD200 million technology transfer deal, while Beijing West Industries Group (BWI) and its global subsidiaries acquired the former Chassis Division of Delphi Corporation (which had been spun off by General Motors in 1999) for USD100 million. Shandong has established research and development centres and associated marketing networks overseas with cumulative approved Chinese-side OFDI of USD870 million by 804 Shandong firms.

\section{OFDI is often based on existing comparative or competitive advantages}

Enterprises with traditional advantages have used these to expand their overseas investments, for example the famous traditional Chinese medicine producer, Beijing Tong Ren Tang Group Company Limited set up three wholly-owned subsidiaries, 13 joint-venture companies and 25 pharmacies in 15 countries and territories supplying branded Chinese medicines to Overseas Chinese communities in a "three-in-one" network of top shops, top doctors and top medicines. Tong Ren Tang established a HKD1.8 billion (USD23 million) production and research base for Chinese medicine and healthcare products in Hong Kong (China).

\section{Some provinces have announced plans for future OFDI development}

A handful of provinces have set out their plans for OFDI development in varying degrees of detail.

Zhejiang plans to promote further development of its OFDI by establishing "regional marketing centres" and encouraging "outstanding industries" to invest abroad. In accordance with the Industry Guidelines for Zhejiang Province Overseas Investment Countries and Territories, the emphasis will be on establishing a set of overseas production bases, overseas R\&D centres and overseas co-operative resource exploitation projects. Over the next five years, Zhejiang will foster the development of 100 internationally-competitive multinational enterprises. The province will accelerate the establishment of economic and trade co-operation zones overseas and actively promote grouped investments in such zones by firms in traditional industries such as, textiles and machinery, starting with pilot projects. Zhejiang will actively promote cross-border M\&As, especially in machinery, textiles, light industry and household electronic appliances.

Shandong plans to maintain an annual increase in OFDI of over $20 \%$ by implementing several policies. It will encourage outstanding productive enterprises in the iron and steel, aluminium oxide, pulp and paper making, oil refining, rubber tyres, textiles and apparel, electronic and electrical household appliances, machinery and equipment, food processing and construction materials industries to invest abroad. Well-established large enterprises in these sectors will be asked to bring small and medium-sized enterprises (SMEs) with them in a coordinated way. The province will accelerate the fostering of multinational enterprises by developing new modes of OFDI co-operation with capital as the bond holding them together. Large enterprises will be expected to develop internationalized management in $\mathrm{R} \& \mathrm{D}$, production and marketing to enable them to raise their position in the global production value chain and strengthen enterprise competitiveness. The province will promote accelerated establishment of overseas R\&D centres and marketing networks, including the 
accelerated establishment of distribution centres for Shandong brands and the acquisition of international brands.

The Hunan provincial government has promulgated a guidance document entitled Working Opinion of the Hunan Province People's Government Concerning Intensified Implementation of the "Go Global" Strategy. In 2005 it set up a special fund for Hunan Province's foreign economic and technological co-operation to provide support for Hunan enterprises in "going global". The province plans that cumulative OFDI will reach USD5 billion by 2015, increasing up to that year at an annual average rate of $22 \%$. The aim is to build large-scale multinational enterprises working together in groups.

Guangdong reports merely that its main policy principle as regards provincial OFDI is the primacy of enterprises and the supporting role of government services.

Provincial authorities in Xinjiang have drawn several conclusions from their experience with outward investments in Central Asia. Firstly, the fundamental factor is human resources. Investment relies on trained manpower. Secondly, OFDI projects have to be beneficial to both sides if they are to be sustainable. Thirdly, not only should Chinese outward-investing enterprises co-operate with host country enterprises and governments, they also have to learn how to co-operate among themselves. To promote more and better OFDI, the Xinjiang government proposes three promotional measures. Firstly, government departments need to give correct guidance to enterprises and improve the level of their service provision and management efficiency. Secondly, government departments need to work in a coordinated way to facilitate "going global". Thirdly, they need to provide information and experiences to enterprises and supply insurance to guard against all kinds of risks.

The overall picture that is emerging is therefore one of regional diversity in both outward FDI policy and performance, with provinces and major cities using their existing competitive advantages to develop appropriate coordinated strategies. There is a clear contrast between the relatively patchy information made available by provincial-level authorities regarding their policies for promoting outward direct investment and the greater detail of (1) their policies to attract inward FDI and (2) central government policies to encourage OFDI. 


\section{CONCLUSION AND POLICY IMPLICATIONS}

\section{The inward FDI regime can be further liberalised}

While the regulatory framework for inward FDI has continued to be streamlined since the 2008 Review, it remains nevertheless relatively restrictive, for example as measured by the OECD's FDI Restrictiveness Index. The latest revision of the Catalogue for Guiding Foreign Investment Industries has, like the two previous revisions, not resulted in any major liberalisation. The OECD continues to offer the Chinese government the policy option of replacing the Catalogue system with a simple closed list, supplemented by an explanation of the reasons for closure where this is not obvious. This change would be easy to implement, as there is already a "prohibited" list that could, with some adjustments, function as the closed list. The "encouraged" catalogue would survive in the publicity material issued by MOFCOM's investment promotion arm and its local affiliates as a simple "shopping list". Existing non-discriminatory incentives offered to domestic and foreign investors alike, including those to attract investment to the Central and Western Regions, would remain. The main change would therefore be the abolition of the "restrictive" catalogue. All remaining sectors would then, as is already the case, be in an unpublished "permitted" category.

Changes in IPR protection legislation made in 2010 in compliance with the WTO judgment should be welcomed. The Chinese authorities should continue to strengthen IPR enforcement, ensure that it is implemented effectively for both domestic and foreign IP holders.

\section{The "go global" policy has been successful}

The "go global" policy has been highly successful in that it has achieved a tremendous acceleration in China's OFDI. Having punched far below its weight in this regard in the first two decades of economic reform, the country now ranks as one of the world's largest exporters of capital. This investment outflow has become more sectorally and geographically diversified, and is no longer limited to state-owned enterprises but now increasingly involves the potentially more dynamic private sector. These flows can be of great benefit to China and the rest of the world, expanding the pool of capital to sustain global growth, while also bringing other, less directly economic, benefits such as promoting innovation and cultural interchange.

The central government has played the main role in promoting OFDI by setting out the "go global" policy goal in unambiguous terms and by gradually relaxing restrictions, cutting red tape, allocating credit for major outward investments and providing information about host countries. Further expansion of OFDI can be achieved by maintaining these policies.

Now that outward investment is a well-established trend, the government may wish to consider putting greater emphasis on making further improvements to the institutional framework for outward 
investment, in particular reducing remaining bureaucratic obstacles, especially the examination and approval process, and improving information, rather than on continuing direct financial involvement in OFDI.

\section{Greater transparency at central level can help maintain rapid OFDI growth}

As the Chinese authorities have recognized, suspicions regarding the intentions behind China's outward investments can impede major investments in other countries. Some of the M\&A deals that have been blocked or discouraged in recent years (such as CNOOC-Unocal and Haier-Maytag in 2005, Huawei-3Com in 2008, Chinalco-Rio Tinto in 2009) have been so large that if they had gone ahead they would have increased China's total annual OFDI outflow by a large percentage. Allaying this suspicion in a systematic and effective way can therefore play a key role in realising the country's potential in maintaining rapid OFDI expansion, while failure to tackle the problem may hold it back. Conducting research into the reasons for these suspicions so that action can be taken to reduce or eliminate them can be more effective than blaming countries for harbouring negative attitudes to Chinese investment.

The Chinese government may therefore wish to consider investing appropriate resources in increasing the transparency of its policies towards outward investment. Such investment can have a disproportionately high pay-back in terms of reducing barriers to major greenfield projects and M\&A deals by Chinese enterprises around the world and may be visible in much higher annual OFDI totals.

First of all, more detailed and understandable OFDI data could be published on a regular basis. The rise of China's OFDI has been so rapid that it has been difficult to keep a timely statistical reporting. While the national-level figures currently published are more complete than those provided by some other countries, they could be improved further, in particular by the collection and publication of more detailed provincial OFDI data.

While China is a unitary state, in fiscal terms it behaves more like a federal state. Many of its provinces are the size of whole countries in terms of land area, population and GDP. From the description above it is clear that they have different policies towards OFDI. Policy-makers could benefit from further analysis of the comparative effectiveness of the policies of the various provinces and province-level municipalities, taking into account their often very different initial conditions, including level of economic development, importance of the private sector, proximity to the sea or to neighbouring countries.

Whether or not the Chinese government already has more complete internal data for in-house research, it is essential to provide more complete publicly-available data so that academic institutions and private-sector entities in China and abroad can conduct research on China's national and provincial OFDI. This is more cost-effective for the Chinese government and can also bring the benefit of allowing more external viewpoints to be brought to bear on policy formulation.

In developing a more complete statistical framework, the Chinese government may wish to consider resuming and expanding its cooperation with the OECD, described in the 2008 Review (OECD 2008). As well as MOFCOM and SAFE, which have already participated in seminars with the 
OECD, the National Bureau of Statistics (NBS) could also be brought into the process, since the NBS is a major end-user of MOFCOM and SAFE statistics. China's OFDI statistics could then be included more fully in the NBS' annual statistical yearbook and the NBS website, which together are the first "port of call" for many analysts.

In 2003, in line with an OECD recommendation (OECD 2003), MOFCOM established a single website focusing on FDI (www.fdi.gov.cn). As the English title of the website, "Invest in China", suggests ${ }^{149}$, this website was originally conceived as an inward investment promotion tool. While it does include OFDI statistics, some material on policies and regulations, lists of outward investment projects, and limited advice for outward investors, it remains overall more oriented towards inward FDI.

MOFCOM may wish to consider establishing a separate website, or a clearly identifiable section of the Invest in China website, devoted exclusively to China's OFDI. With improved navigability, this site could present OFDI data series in understandable form, e.g. tables and charts showing annual data series, rather than the current presentation, which requires searching for individual data points. It could also be an invaluable source of provincial-level data, presented both separately and in aggregate. This would be far more convenient for researchers and policy-makers than the development of individual provincial-level OFDI websites.

\section{Provinces can benefit from greater policy and data transparency}

Province-level governments have also played their part in promoting OFDI, but their role is unclear because they have been less informative on this than the central government, which has been the main driver of the policy. They have also been less informative on OFDI policies and statistics than they have been about inward FDI, which has been the subject of strong inter-provincial competition to attract outsiders.

Nevertheless, from the limited information available we have shown (above) that there are clear differences between provinces in their policies towards OFDI in such aspects as the date of adoption of the "go global" policy, the predominance of state-owned or private-sector enterprises, and the geographical reach of OFDI. Further research is needed to determine the extent to which these differences result from variations in initial conditions and which are the result of more or less effective policies, so that lessons can be learned for future policy-making at the provincial level.

The recommendation that the central government consider increasing the transparency of its policies towards FDI and of FDI data applies also at the provincial level. Provinces can help reduce barriers to outward investment projects and M\&A deals by enterprises within their jurisdiction by providing fuller information. For example, provincial and municipal governments could issue more brochures on OFDI similar to those on inward investment that they distribute to potential foreign investors.

${ }^{149}$ The title in Chinese is “中国投资指南”, i.e. “China Investment Guide”. 
Such publicity could include instructions and advice given by local governments to outwardinvesting enterprises on compliance with international and local standards of corporate behaviour, where these exist. Where they do not exist, local governments are encouraged to work collectively, with the central government and with institutions in host countries to develop them. Because it is localized and concrete, this information could be a vital supplement to central government publicity regarding national policies to promote responsible business conduct. Providing convincing reassurance to host communities that Chinese enterprises have serious domestic obligations to respect host-country laws and societal expectations beyond the law could make the difference between acceptance and rejection of a major investment. 


\section{GLOSSARY}

$\begin{array}{ll}\text { CNY } & \text { Chinese yuan (renminbi) } \\ \text { FDI } & \text { Foreign direct investment } \\ \text { FIE } & \text { Foreign-owned enterprise } \\ \text { GDP } & \text { Gross domestic product } \\ \text { IFDI } & \text { Inward foreign direct investment } \\ \text { IPR } & \text { Intellectual property rights } \\ \text { M\&A } & \text { Merger and acquisition } \\ \text { MOFCOM } & \text { Ministry of Commerce of the People's Republic of China } \\ \text { NDRC } & \text { National Development and Reform Commission of the People's Republic of China } \\ \text { OFDI } & \text { Outward foreign direct investment } \\ \text { SME } & \text { Small and medium-sized enterprise } \\ \text { SOE } & \text { State-owned enterprise } \\ \text { WFOE } & \text { Wholly-foreign-owned enterprises } \\ \text { WTO } & \text { World Trade Organisation }\end{array}$




\section{REFERENCES}

\section{Bibliography}

American Chamber of Commerce in China (Amcham-China) (2011), American Business in China: 2011 White Paper, Beijing.

Antkiewicz, Agata and John Whalley (2007), "Recent Chinese Buyout Activity and the Implications for Global Architecture”, Canadian Public Policy Journal, 33 (2).

A.T. Kearney (2010), Investing in a Rebound: The 2010 A.T. Kearney FDI Confidence Index, Vienna, Virginia.

Bachrack, Matthew, Cunzhen Huang and Jay Modrali (2009), Merger Control under China's Antimonopoly Law: The First Year, China Business Review.

Bonaglia, Federico, Andrea Goldstein and John A. Mathews (2007), “Accelerated internationalization by emerging markets' multinationals: The case of the white goods sector", Journal of World Business, 42(4), pp. 369-383.

Bosshart, Stephan, Thomas Luedi and Emma Wang (2010), "Past Lessons for China's new joint ventures", McKinsey Quarterly, December.

Broadman, Harry G. (2011), The backstory of China and India's growing investment and trade with Africa: Separating the wheat from the chaff, Columbia FDI Perspectives, No. 34, Vale Columbia Center on Sustainable International Investment, New York.

Buckley, Peter, Jeremy Clegg, Adam R. Cross, Xin Liu, Hinrich Voss and Ping Zheng (2007), The determinants of Chinese outward foreign direct investment, University of Westminster, London.

Buckley, Peter, Adam R. Cross, Hui Tan, Liu Xin and Hinrich Voss (2008), "Historic and Emergent Trends in Chinese Outward Direct Investment", Management International Review, 48(6), pp. 715-748.

Centre for International Governance Innovation (CIGI) (2008), China's New Economic Diplomacy: Workshop Report, retrieved from www.cigionline.org. 
Cheng, Leonard and Zihui Ma (2009), "China's Outward FDI: Past and Future”, in Feenstra, Robert and Shangjin Wei, eds., China's Growing Role in World Trade, University of Chicago Press, Chicago, pp. 545-578.

Cheng, Shaoming and Roger R. Stough (2008), The Pattern and Magnitude of China's Outward FDI in Asia, in Rajan, Ramkishen, Rajiv Kumar and Nicola Virgill, eds., New Dimensions of Economic Globalization. Surge of Outward Foreign Direct Investment from Asia, World Scientific, Singapore, pp. 115-140.

Cheung, Yin-Wong and Xingwang Qian (2009), "The Empirics of China's Outward Direct Investment”, Pacific Economic Review, 14(3), pp. 312-341.

Child, John and Suzana B. Rodrigues (2005), "The Internationalization of Chinese Firms: A Case for Theoretical Extension”, Management and Organization Review, 1(3), pp. 381-410.

China Council for the Promotion of International Trade (CCPIT) (2010), Survey on Current Conditions and Intention of Outbound Investment by Chinese Enterprises, Beijing.

China Labour Bulletin (2011), Unity is Strength: The Workers' Movement in China 20092011, Hong Kong.

Cross, Adam R. and Hinrich Voss (2008), Chinese direct investment in the United Kingdom: An assessment of motivations and competitiveness, research paper, Leeds University Business School, Leeds.

Davies, Ken (2009), While global FDI falls, China's outward FDI doubles, Columbia FDI Perspectives, No. 5, Vale Columbia Center on Sustainable International Investment, New York.

Davies, Ken (2010a), Inward FDI from China and its policy context, Columbia FDI Profiles, Vale Columbia Center on Sustainable International Investment, New York.

Davies, Ken (2012), Inward FDI from China and its policy context, Columbia FDI Profiles, Vale Columbia Center on Sustainable International Investment, New York, http://www.vcc.columbia.edu/files/vale/documents/China_IFDI_final_xxxxxx.pdf.

Davies, Ken (2010b), Outward FDI from China and its policy context, Columbia FDI Profiles, Vale Columbia Center on Sustainable International Investment, New York.

Davies, Ken (2012a), Outward FDI from China and its policy context, Columbia FDI Profiles, Vale Columbia Center on Sustainable International Investment, New York, http://www.vcc.columbia.edu/files/vale/documents/China_OFDI_final_xxxxx.pdf. 
Davies, Ken and Karl P. Sauvant (2010), What will an appreciation of China's currency do to inward and outward FDI?, Columbia FDI Perspectives, No. 30, Vale Columbia Center on Sustainable International Investment, New York.

De Gucht Karel (2011), "Looking beyond the crisis: Making the EU-China trade relations work", speech at EU-China High Level Political Forum 2011, Brussels, 8 November.

Deng, Ping (2007), "Investing for strategic resources and its rationale: The case of outward FDI from Chinese companies", Business Horizons, 50(1), pp.71-81.

Deng, Ping (2009), "Why do Chinese firms tend to acquire strategic assets in international expansion?", Journal of World Business, 44(1), pp. 74-84.

European Chamber of Commerce in China (2010), European Chamber Business Confidence Survey 2010, Beijing.

European Chamber of Commerce in China (2011), European Chamber Business Confidence Survey 2011, Beijing.

European Commission, International Monetary Fund, Organisation for Economic Cooperation and Development, United Nations and World Bank (2009), System of National Accounts, New York.

Fudan University School of Management and Vale Columbia Center for Sustainable International Investment (2008), Chinese Multinationals Make Steady Progress: 2007 ranking of Chinese multinational enterprises, Vale Columbia Center on Sustainable International Investment, New York.

Fudan University School of Management and Vale Columbia Center for Sustainable International Investment (2009), Second ranking survey finds strong growth in the foreign assets of Chinese multinationals, Vale Columbia Center on Sustainable International Investment, New York.

Fudan University School of Management and Vale Columbia Center for Sustainable International Investment (2010), Chinese Multinationals gain further momentum, Vale Columbia Center on Sustainable International Investment, New York.

Gao, Lan (2008), Determinants of China's Outward Foreign Direct Investment, Paper presented to Chinese Economic Association (UK) Conference, London.

Gestrin, Michael (2011), "International Mergers and Acquisition Surge in 2011", Investment News, 16.

Global Environmental Institute (2011), Environmental Policies on China's Investment Overseas, China Environmental Science Press, Beijing. 
He, Wei and Marjorie A. Lyles, China's outward foreign direct investment, Business Horizons (2008) 51, pp. 485-491, Bloomington, Indiana.

Japanese Chamber of Commerce and Industry in China (2011), 2011 White Paper on the Chinese Economy and Japanese Companies, Beijing.

Jiang, Julie and Jonathan Sinton (2011), Overseas Investments by China's National Oil Companies: Assessing the drivers and impacts, International Energy Agency (IEA), Paris.

Li, Cheng (2011), "China's Midterm Jockeying: Gearing up for 2012: Part 4: Top Leaders of Major State-Owned Enterprises”, China Leadership Monitor, No. 34, pp. 1-31, Hoover Institution, Stanford University.

Liu, Xiaohui, Trevor Buck and Chang Shu (2005), "Chinese economic development, the next stage: outward FDI?” International Business Review, 14, pp. 97-115.

Luo, Yadong, Qiuzhi Xue and Binjie Han (2010), "How emerging market governments promote outward FDI: Experience from China”, Journal of World Business, 45, pp. 68-79.

Min, Zhu, Cai Jinqing and Marrha Avery, eds. (2009), China's Emerging Financial Markets: Challenges and Global Impact, John Wiley, Singapore.

Ministry of Commerce of the People's Republic of China (MOFCOM) (2010a), 2009

Statistical Bulletin of China's Outward Foreign Direct Investment (2009

年度对外直接投资统计公报 2009 niandu duiwai zhijie touzi tongji gongbao) [Chinese],

Beijing.

Ministry of Commerce of the People's Republic of China (MOFCOM) (2011), 2010

Statistical Bulletin of China's Outward Foreign Direct Investment (2009

年度对外直接投资统计公报 2010 niandu duiwai zhijie touzi tongji gongbao) [Chinese], Beijing.

Ministry of Commerce of the People's Republic of China (MOFCOM) (2010b), Report on Development of China's Outward Investment and Economic Cooperation (中国对外投资合作发展报告) [Chinese], Shanghai Jiaotong University Press, Shanghai.

Ha, Hanna, John Hickin, and Gerry O'Brien (2011), China: Merger Control, The Asia-Pacific Anti-Trust Review, Global Competition Review, retrieved from http://www.globalcompetitionreview.com.

Li, Cheng (2009), Reclaiming the "Head of the Dragon": Shanghai as China's Center for International Finance and Shipping, China Leadership Monitor, No.28, Hoover Institute, Stanford University, Stanford. 
Morck, Randall, Bernard Yeung and Minyuan Zhao (2008), "Perspectives on China's Outward Foreign Direct Investment”, Journal of International Business Studies, 39(3), pp. 337-350.

Ning, Lutao (2009), China's Rise in the World ICT Industry: Industrial strategies and the catch-up development model, Routledge, London.

OECD (2003), Investment Policy Review of China: Progress and Reform Challenges, Paris. OECD (2006), Investment Policy Review of China: Open Policies towards Mergers and Acquisitions, Paris.

OECD (2008), Investment Policy Review of China: Encouraging Responsible Business Conduct, Paris.

OECD (2008a), OECD Benchmark Definition of Foreign Direct Investment, Fourth Edition, Paris.

Ozawa, Terutomo and Christian Bellak (2010), Will China relocate its labor-intensive factories to Africa, flying geese style?, Columbia FDI Perspectives, No. 28, Vale Columbia Center on Sustainable International Investment, New York.

Rasiah, Rajah, Peter Gammeltoft and Yang Jiang (2010), "Home government policies for outward FDI from emerging economies: lessons from Asia”, International Journal of Emerging Markets, 5(3/4).

Redding, Gordon and Michael A. Witt (2007), The Future of Chinese Capitalism, Oxford University Press, Oxford.

Rugman, Alan M. and Jing Li (2007), "Will China's Multinationals Succeed Globally or Regionally?”, European Management Journal, 25(5), pp. 333-343.

Rui, Huaichuan and George S. Yip (2008), "Foreign acquisitions by Chinese firms: A strategic intent perspective", Journal of World Business, 43(2), pp. 213-226.

Satyanand, Premila Nazareth (2010), How BRIC MNEs Deal with International Political Risk, Columbia FDI Perspectives, No. 22, Vale Columbia Center on Sustainable International Investment, New York.

Sauvant, Karl P., ed. (2010), Investing in the United States: Is the U.S. Ready for FDI From China?,: Edward Elgar, Cheltenham.

Thomsen, Stephen (2011), "Korea Emerges as the Biggest Reformer of FDI Restrictions since 1997”, Investment News, 16. 
United Nations Conference on Trade and Development (UNCTAD) (2006), World Investment Report 2006: Investment from Developing and Transition Economies: Implications for Development, Geneva.

United Nations Conference on Trade and Development (UNCTAD) (2010), World Investment Report 2010: Investing in a low-carbon economy, Geneva.

Woo, Yuen Pau and Kenny Zhang (?), China Goes Global: The Implications of Chinese Outward Direct Investment for Canada.

Zafar, Ali (2007), “The Growing Relationship Between China and Sub-Saharan Africa: Macroeconomic, Trade, Investment, and Aid Links", The World Bank Research Observer, 22(1), pp. 103-130.

Zhang, Xinzhu and Vanessa Yanhua Zhang (2010), "Chinese Merger Control: Patterns and Implications", Journal of Competition Law and Economics, 6(2), pp. 477-496.

Zhang, Zhiming (2010), Inside the growth engine: A guide to China's regions, provinces, and cities, HSBC Global Research, Hong Kong (China).

Zhao, Shasha (2007), Chinese Outward Foreign Direct Investment - A driving force for further economic development, unpublished student dissertation, Université de Montréal, Montreal. 


\section{Websites}

Central People's Government of the People's Republic of China

(中华人民共和国中央人民政府 zhonghua renmin gongheguo zhongyang renmin zhengfu) website [Chinese/English]: http://www.gov.cn.

China Court (中国法院网 zhongguo fayuan wang) website (maintained by the Supreme People's Court of the People's Republic of China) [Chinese/English]:

http://www.chinacourt.org.

China Economic Monitoring and Analysis Centre (CEMAC, 中国经济景气监测中心 zhongguo jingji jingqi jiance zhongxin) website (maintained by the National Bureau of Statistics of the People's Republic of China) [Chinese]: http://www.cemac.org.cn

Communist Party of China News Web (中国共产党新闻网 zhongguo gongchandang xinwen wang) website [Chinese/English]: http://cpc.people.com.cn.

Hong Kong Trade Development Council [English]: http://www.hktdc.com.

International Monetary Fund (IMF) [English]: http://www.imf.org.

Invest in China (中国投资指南 zhongguo touzi zhinan) website (maintained by the Ministry of Commerce of the People's Republic of China FDI site) [Chinese/English]:

http://www.fdi.gov.cn

Ministry of Commerce of the People's Republic of China (中华人民共和国商务部 zhonghua renmin gongheguo shangwu bu) website [Chinese/English]: http://www.mofcom.gov.cn.

National Bureau of Statistics of the People's Republic of China

(中华人民共和国国家统计局 zhonghua renmin gongheguo guojia tongji ju) website [Chinese/English]: http://www.stats.gov.cn.

National Development and Reform Commission of the People's Republic of China (NDRC, 中华人民共和国国家发展和改革委员会zhonghua renmin gongheguo fazhan he gaige weiyuanhui) website: http://www.ndrc.gov.cn.

Organisation for Economic Co-operation and Development (OECD) statistics website [English]: http://stats.oecd.org.

People's Bank of China (PBoC, 中国人民银行 zhongguo renmin yinhang) website [Chinese/English]: http://www.pbc.gov.cn.

State Administration of Foreign Exchange (SAFE, 国家外汇管理局 guojia waihui guanli ju) website [Chinese/English]: http://www.safe.gov.cn. 
United Nations Conference on Trade and Development (UNCTAD) website [English]: http://www.unctad.org.

World Bank data [English]: http://data.worldbank.org.

XinhuaNet [English]: http://news.xinhuanet.com

N.B. Chinese-language versions of official Chinese websites are often more complete and upto-date than the English-language versions and are generally regarded as authoritative. 
ANNEX 1 STATISTICAL TABLES

Table A.1. FDI inflows, 1979-2010

\begin{tabular}{|c|c|c|}
\hline & Projects newly contracted & Realised FDI inflows (USD million) \\
\hline 1979-1982 & 920 & 1,769 \\
\hline 1983 & 638 & 916 \\
\hline 1984 & 2,166 & 1,419 \\
\hline 1985 & 3,073 & 1,956 \\
\hline 1986 & 1,498 & 2,244 \\
\hline 1987 & 2,233 & 2,314 \\
\hline 1988 & 5,945 & 3,194 \\
\hline 1989 & 5,779 & 3,393 \\
\hline 1990 & 7,273 & 3,487 \\
\hline 1991 & 12,978 & 4,366 \\
\hline 1992 & 48,764 & 11,008 \\
\hline 1993 & 83,437 & 27,515 \\
\hline 1994 & 47,549 & 33,767 \\
\hline 1995 & 37,011 & 37,521 \\
\hline 1996 & 24,556 & 41,726 \\
\hline 1997 & 21,001 & 45,257 \\
\hline 1998 & 19,799 & 45,463 \\
\hline 1999 & 16,918 & 40,319 \\
\hline 2000 & 22,347 & 40,715 \\
\hline 2001 & 26,140 & 46,878 \\
\hline 2002 & 34,171 & 52,743 \\
\hline 2003 & 41,081 & 53,505 \\
\hline 2004 & 43,664 & 60,630 \\
\hline 2005 & 44,019 & 60,325 \\
\hline 2006 & 41,485 & 69,468 \\
\hline 2007 & 37,888 & 82,658 \\
\hline 2008 & 27,514 & 92,395 \\
\hline 2009 & 23,435 & 90,033 \\
\hline 2010 & 27,406 & 105,735 \\
\hline 2011 & 27,712 & 117,698 \\
\hline 2012 & 24,925 & 113,294 \\
\hline
\end{tabular}

Source: MOFCOM website: www.fdi.gov.cn 
Table A.2. Mode of utilising FDI (realised FDI value in USD million)

\begin{tabular}{|lrrrr|}
\hline & $\mathbf{2 0 0 9}$ & $\mathbf{2 0 1 0}$ & $\mathbf{2 0 1 1}$ & $\mathbf{2 0 1 2}$ \\
\hline Equity joint venture & 17,273 & 22,498 & 21,415 & 21,706 \\
\% of total FDI & 19.2 & 21.3 & 18.5 & 19.4 \\
Contractual joint venture & 2,034 & 1,616 & 1,757 & 2,308 \\
\% of total FDI & 2.3 & 1.5 & 1.5 & 2.1 \\
Wholly-foreign-owned enterprise & 68,682 & 80,975 & 91,205 & 86,132 \\
\% of total FDI & 76.3 & 76.6 & 78.6 & 77.1 \\
Share company with foreign investment & 2,044 & 646 & 1,634 & 1,570 \\
\% of total FDI & 2.3 & 0.6 & 1.4 & 1.4 \\
\hline Total FDI & $\mathbf{9 0 , 0 3 3}$ & $\mathbf{1 0 5 , 7 3 5}$ & $\mathbf{1 1 6 , 0 1 1}$ & $\mathbf{1 1 1 , 7 1 6}$ \\
\hline
\end{tabular}

Source: MOFCOM website: www.fdi.gov.cn. 
Table A.3. Sectoral distribution of FDI in 2010 (realised FDI in USD million)

\begin{tabular}{|c|c|c|c|c|}
\hline Sector & $\begin{array}{l}\text { No. of } \\
\text { projects }\end{array}$ & Share \% & $\begin{array}{l}\text { Realised } \\
\text { value }\end{array}$ & Share \% \\
\hline $\begin{array}{l}\text { Agriculture, forestry, animal } \\
\text { husbandry \& fishery }\end{array}$ & 929 & 3.4 & 1,912 & 1.7 \\
\hline Mining & 92 & 0.3 & 684 & 0.6 \\
\hline Manufacturing & 11,047 & 40.3 & 49,591 & 43.2 \\
\hline $\begin{array}{l}\text { Production \& supply of power, gas } \\
\text { and water }\end{array}$ & 210 & 0.8 & 2,125 & 1.9 \\
\hline Construction & 276 & 1.0 & 1,461 & 1.3 \\
\hline $\begin{array}{l}\text { Transport, warehousing, post \& } \\
\text { telecommunications }\end{array}$ & 396 & 1.4 & 2,244 & 2.0 \\
\hline Computer and software & 1,046 & 3.8 & 2,487 & 2.2 \\
\hline Wholesale and retail & 6,786 & 24.8 & 6,596 & 5.8 \\
\hline Hotel and restaurant & 579 & 2.1 & 935 & 0.8 \\
\hline Finance & 99 & 0.4 & 10,122 & 8.8 \\
\hline Real estate & 689 & 2.5 & 23,986 & 20.9 \\
\hline Leasing and business services & 3,418 & 12.5 & 7,130 & 6.2 \\
\hline $\begin{array}{l}\text { Scientific research, technological } \\
\text { services and geological prospecting }\end{array}$ & 1,299 & 4.7 & 1,967 & 1.7 \\
\hline $\begin{array}{l}\text { Management of water conservancy, } \\
\text { environment and public equipment }\end{array}$ & 143 & 0.5 & 909 & 0.8 \\
\hline Residential and related services & 217 & 0.8 & 20.53 & 1.8 \\
\hline Education & 12 & 0.0 & 8 & 0.0 \\
\hline $\begin{array}{l}\text { Healthcare, social security \& social } \\
\text { welfare }\end{array}$ & 12 & 0.0 & 90 & 0.1 \\
\hline $\begin{array}{l}\text { Culture, physical education and } \\
\text { entertainment }\end{array}$ & 168 & 0.6 & 436 & 0.4 \\
\hline $\begin{array}{l}\text { Public management and social } \\
\text { organisation }\end{array}$ & 2 & 0.0 & 0 & 0.0 \\
\hline
\end{tabular}

Source: MOFCOM Invest in China website www.fdi.gov.cn. 
Table A.4. Exports and imports of foreign-invested enterprises in China (USD billion)

\begin{tabular}{|lrrrrrrrr|}
\hline & $\mathbf{2 0 0 5}$ & \% of total & $\mathbf{2 0 0 6}$ & \% of total & $\mathbf{2 0 0 7}$ & \% of total & $\mathbf{2 0 0 8}$ & \% of total \\
\hline Exports & 444.2 & 58.3 & 563.8 & 58.2 & 695.5 & 57.1 & 790.6 & 55.3 \\
Imports & 387.5 & 58.7 & 472.6 & 59.7 & 559.4 & 58.5 & 620.0 & 54.7 \\
\hline Total & 831.7 & 58.5 & $1,036.5$ & 58.2 & $1,254.9$ & 57.7 & $1,410.6$ & 55.1 \\
\hline
\end{tabular}

Source: MOFCOM website: www.fdi.gov.cn.

Table A.5. Share of FIE Industrial Output in Total Industrial Output (CNY billion)

\begin{tabular}{|rrrr|}
\hline & National industrial output & FIE industrial output & \% share \\
\hline 2005 & $24,962.50$ & $7,839.90$ & 31.4 \\
2006 & $31,563.00$ & $9,942.10$ & 31.5 \\
2007 & $40,448.90$ & $12,503.70$ & 30.9 \\
2008 & 49624.9 & 14758.4 & 29.7 \\
2009 & $54,632.00$ & $15,267.36$ & 27.95 \\
2010 & $70,777.72$ & $19,179.28$ & 27.1 \\
\hline
\end{tabular}

Source: MOFCOM website: www.fdi.gov.cn. 
Table A.6. China OFDI stock by sector in 2010 (USD billion)

\begin{tabular}{|lr|}
\hline Leasing and business services & 61,406 \\
Finance & 45,091 \\
Wholesale and retail & 35,736 \\
Mining and exploration & 20,520 \\
Transport, communications, warehousing and post & 18,620 \\
Residential property & 5,937 \\
Manufacturing & 5,243 \\
Residential and other services & 2,556 \\
Water conservancy, environment and public facilities management & 1,128 \\
Information transmission, computer service and software & 830 \\
Construction & 686 \\
Technology services and geological surveying & 475 \\
Electricity, gas and water supply & 337 \\
Accommodation and catering & 189 \\
Other & 126 \\
\hline
\end{tabular}

Source: MOFCOM Invest in China website www.fdi.gov.cn.

Table A.7. Percentage distribution of China OFDI stock by ownership type at end-2010

\begin{tabular}{|lr|}
\hline State-owned enterprises & 66.2 \\
Limited liability companies & 23.6 \\
Companies limited by shares & 6.1 \\
Private enterprises & 1.5 \\
Shareholding co-operatives & 1.1 \\
Foreign-invested enterprises & 0.7 \\
Collective enterprises & 0.2 \\
Hong Kong, Macau (China) and Taiwan enterprises & 0.1 \\
Other & 0.5 \\
\hline
\end{tabular}

Source: MOFCOM Invest in China website www.fdi.gov.cn.

Table A.8. Percentage geographical distribution of China's OFDI stock in 2010

\begin{tabular}{|ll|}
\hline Asia & 71.9 \\
Latin America & 13.8 \\
Europe & 5.0 \\
Africa & 4.1 \\
Oceania & 2.7 \\
North America & 2.5 \\
\hline
\end{tabular}

Source: MOFCOM Invest in China website www.fdi.gov.cn. 
Table. A.9. China's non-financial OFDI stock by provincial level unit in 2010 (USD million)

\begin{tabular}{|c|c|c|}
\hline Beijing Municipality & 766.1 & $4.9 \%$ \\
\hline Tianjin Municipality & 341.3 & $2.2 \%$ \\
\hline Hebei Province & 532.4 & $3.4 \%$ \\
\hline Shanxi Province & 79.3 & $0.5 \%$ \\
\hline Inner Mongolia Autonomous Region & 80.4 & $0.5 \%$ \\
\hline Liaoning Province & $1,935.7$ & $12.3 \%$ \\
\hline Dalian Municipality & $1,632.3$ & $10.4 \%$ \\
\hline Jilin Province & 213.4 & $1.4 \%$ \\
\hline Heilongjiang Province & 237.8 & $1.5 \%$ \\
\hline Shanghai Municipality & $1,584.7$ & $10.0 \%$ \\
\hline Jiangsu Province & $1,371.2$ & $8.7 \%$ \\
\hline Zhejiang Province & $2,679.2$ & $17.0 \%$ \\
\hline Ningbo Municipality & 228.8 & $1.5 \%$ \\
\hline Anhui Province & 813.7 & $5.2 \%$ \\
\hline Fujian Province & 535.0 & $3.4 \%$ \\
\hline Xiamen Municipality & 228.8 & $1.5 \%$ \\
\hline Jiangxi Province & 94.7 & $0.6 \%$ \\
\hline Shandong Province & $1,890.0$ & $12.0 \%$ \\
\hline Qingdao Municipality & 462.0 & $2.9 \%$ \\
\hline Henan Province & 118.6 & $0.8 \%$ \\
\hline Hubei Province & 80.6 & $0.5 \%$ \\
\hline Hunan Province & 274.8 & $1.7 \%$ \\
\hline Guangdong Province & $1,599.8$ & $10.1 \%$ \\
\hline Shenzhen Municipality & 608.8 & $3.9 \%$ \\
\hline Shaanxi Province & 260.6 & $1.7 \%$ \\
\hline Gansu Province & 101.8 & $0.6 \%$ \\
\hline Qinghai Province & 1.4 & $0.0 \%$ \\
\hline Ningxia Hui Autonomous Region & 7.1 & $0.0 \%$ \\
\hline Xinjiang Uygur Autonomous Region & 47.8 & $0.3 \%$ \\
\hline Xinjiang Production and Reconstruction Corps & 121.1 & $0.8 \%$ \\
\hline Total & $15,768.1$ & $100.0 \%$ \\
\hline
\end{tabular}

Source: MOFCOM Invest in China website www.fdi.gov.cn. 

미) OECD 